First draft: June 6, 2009

This draft: September 22, 2009

\title{
Rescuing Banks from the Effects of the Financial Crisis
}

\author{
by
}

\author{
Michele Fratianni* and Francesco Marchionne**
}

\begin{abstract}
$\underline{\text { Abstract }}$
This paper examines government policies aimed at rescuing banks from the effects of the great financial crisis of 2007-2009. To delimit the scope of the analysis, we concentrate on the fiscal side of interventions and ignore, by design, the monetary policy reaction to the crisis. The policy response to the subprime crisis started in earnest after Lehman's failure in mid September 2008, accelerated after February 2009, and has become very large by September 2009. Governments have relied on a portfolio of intervention tools, but the biggest commitments and outlays have been in the form of debt and asset guarantees, while purchases of bad assets have been very limited. We employ event study methodology to estimate the benefits of government interventions on banks and their shareholders.

Announcements directed at the banking system as a whole (general) and at specific banks (specific) were priced by the markets as cumulative abnormal rates of return over the selected window periods. General announcements tend to be associated with positive cumulative abnormal returns and specific announcements with negative ones. General announcements exert cross-area spillovers but are perceived by the home-country banks as subsidies boosting the competitive advantage of foreign banks. Specific announcements exert spillovers on other banks. Our results are also sensitive to the information environment. Specific announcements tend to exert a positive impact on rates of return in the pre-crisis sub-period, when announcements are few and markets have relative confidence in the "normal" information flow. The opposite takes place in the turbulent crisis sub-period when announcements are the order of the day and markets mistrust the "normal" information flow. These results appear consistent with the observed reluctance of individual institutions to come forth with requests for public assistance.
\end{abstract}

JEL Classification: G01, G21, N20

Keywords: announcements, financial crisis, rescue plans, undercapitalization.

* Corresponding author, Indiana University, Kelley School of Business, Bloomington, Indiana (USA), Università Politecnica delle Marche and MoFiR, Ancona (Italy), email: fratiann@indiana.edu. ** Università Politecnica delle Marche and MoFiR, Ancona (Italy), email: f.marchionne@univpm.it. Paper prepared for the Conference on The Changing Geography of Money, Banking and Finance in a Post-Crisis World, Università Politecnica delle Marche, Ancona, 8-9 October, 2009. As we were writing the second draft of this paper, we uncovered on the Web site of the Bank for International Settlements a study on the same subject dated July 2009 (BIS Paper n. 48). 


\section{INTRODUCTION}

This paper examines government policies aimed at rescuing banks from the effects of the great financial crisis of 2007-2009. To delimit the scope of the analysis, we will concentrate on the fiscal side of interventions and will ignore, by design, the monetary policy reaction to the crisis (in essence, we will ignore inflation as a possible crisis exit). The paper is organized in three parts. The first (Section II) gives a description of the subprime crisis that fits many aspects of a credit-boom-andbust-cycle (CBB, for short) hypothesis. Crises, on the other hand, have idiosyncratic features. The distinctive characteristic of this crisis has been the creation of complex and opaque assets and the transfer of these assets from the balance sheet of banks to the markets. The subprime crisis, as is well known by now, has been big in terms of geographical coverage, number of failed and rescued banks, and real sector spillovers. Over a 19-month period starting at the end of July of 2007, a representative sample of 120 large banks from the United States, Western Europe and the Pacific region lost \$3.23 trillion of market capitalization. The depth of the crisis cannot be explained only by deteriorating fundamentals; as predicted by the CBB hypothesis, the bust that followed the boom led to a sharply rising risk aversion of the investing public.

The second part (Section III) reviews the long list of government announcements to rescue the banking system after the failure of Lehman Brothers in mid September 2008. We provide quantitative summaries of both commitments and actual disbursements using alternative sources. ${ }^{1}$ The data available suggest that governments have employed a mixture of bank asset and debt guarantees, equity funding, and purchases of poor-quality assets. Opaque but politically attractive guarantees have the dominant weight in this portfolio.

\footnotetext{
${ }^{1}$ This is work in progress because, at the time of writing (September 2009), governments are far from finished with their rescue interventions.
} 
The third part (Section IV) employs event study methodology to estimate the benefits of government interventions on banks and their shareholders. The hypothesis is that the announcement of a rescue plan is credible if it affects rates of return of the targeted banks. We test for these effects by computing cumulative abnormal returns of the participating banks around a window that includes announcement dates. Government announcements of rescue plans are either aimed at the entire banking system or at specific banks. We perform three separate tests on our sample of large banks. One test estimates, with panel data, the overall impact on banks' equity valuation of the two types of government rescue announcements; another estimates cross-area spillover effects of the first announcement type; and a third one estimates cross-bank spillover effects of the second announcement type. Our findings suggest that announcements have exerted a statistically significant and economically relevant impact on banks' equity valuation over the announcement window. We draw conclusions about our study in Section V.

\section{THE SUBPRIME CRISIS AS A CREDIT BOOM AND BUST CYCLE}

There is a long tradition in economics of associating financial crises with credit booms and busts that give rise to booms and busts in banking and securities markets; see, among others, Mitchell (1913), Fisher (1933), Minsky (1977), and Kindleberger (1978). A crisis starts with a macro shock or displacement that alters the profit outlook in the economy. To this follows an expansion of bank credit that feeds the economic boom. Firms expand debt relative to equities to finance new projects based on optimistic assessments of future profits. Optimism about the future drives the process of capital and debt accumulation. Monetary expansion comes with or promotes the expansion of bank credit. Prices of specific assets increase, leading to a state of euphoria or mania. Herding behavior is an integral part of manias or fads. Then, an event (e.g., real estate price implosion or a large bank 
failure) occurs that triggers a reversal in expectations and wakes up investors that assets are badly overpriced. The disturbance must be such to alter fundamentally future anticipated profits. Asset prices implode as speculators unload risky assets. The interaction between profits and speculation sets up a vicious circle that drives up interest rates and leads to a rush for liquidity. In the panic phase of debt liquidation, inflation falls below expectations. Disinflation forces a rise in the real value of debt and debtors suffer a decline in net worth. Business contraction occurs through debt deflation. Even in the absence of disinflation, the same mechanism is operative through a decline in asset prices that reduces the value of collateral and forces borrowers to put up more security for a given nominal value of debt. The end result is that banks become fragile and governments respond by providing public assistance; see Fratianni (2008). While policy makers tend to argue that government intervention is superior to the alternative of letting banks fail, the injection of public funds in banking involves not only large current costs but also large future ones by inducing more opportunistic behavior on the part of banks (for example, the too-big-too-fail policy).

\section{Unique features of the subprime crisis}

The subprime crisis has many features of the timeline implied by the CBB hypothesis. Yet, as it is true for other crises, some characteristics are unique to this crisis, such as the transfer of assets from the balance sheets of banks to the markets, the creation of complex and opaque assets, the failure of ratings agencies to properly assess the risk of such assets, and the application of fair value accounting. Subprime mortgages were an innovation of the 1990s, spurred by the demise of usury laws, financial deregulation, and the Community Reinvestment Act of 1977 that gave incentives to lenders to extend loans to individuals with low income and limited or outright poor credit histories (Gramlich 2007). The Act was accompanied by "regulatory relief", especially with regard to the two government-sponsored agencies, Fannie Mae and Freddie Mac (Wallison 2009). 
In 1994, subprime loans were five percent of total mortgage origination; by 2005, it had risen to 20 percent. Over the period 1994-2005, this market grew at an average annual growth rate of 26 percent and expanded home ownership by an estimated 12 million units. A great deal of subprime origination was made by independent, federally unregulated, lenders who applied adjustable interest rates and often so-called teaser rates. Practices, such as excluding taxes and interest rates from escrow accounts and prepayment penalties, were widespread. All of this was driven by the property boom.

The credit boom and the politics of lending led to a progressive deterioration of credit standards from 2001 to 2007 (Demyanyk and van Hembert forthcoming). Simple descriptive statistics show a negative correlation between changes in the quantity of subprime loans and changes in denial rates on subprime loan applications, and a positive correlation between changes in the quantity of subprime loans and changes in the ratio of loan size to borrower's income (Dell'Ariccia et al. 2008, Figure 4). Declining lending standards were correlated with rapid home price appreciation, evidence that is consistent with the hypothesis that the housing boom was driving both the expansion of credit and declining lending standards. Finally, an expansive monetary policy was providing added impetus to a loosening of the standards (Dell'Ariccia et al. 2008, especially p. 18). The link between CBB and monetary policy is hardly surprising; for a review of the evidence see Berger and Udell (2004).

Actual and projected write-downs on low-quality mortgages represent approximately 25 percent of estimated losses on prime, commercial real estate, and consumer and corporate loans; and 9 percent of the estimated mark-to-market losses on asset-backed securities (ABS), collateralized debt obligations (CDO), prime mortgage-backed securities (MBS), collateralized MBS (CMBS), collateralized loan obligations (CLO), and corporate debt; see IMF (2008a, Table 1.1). ${ }^{2}$ Large default rates on subprime mortgages cannot explain the depth of this crisis. Subprime mortgages were the accelerant to the fire after the real estate bust short circuited in the financial house. The fire spread

\footnotetext{
${ }^{2}$ The estimate of total losses, as of October 2008, is placed at $\$ 1,405$ billion.
} 
quickly and globally because this house was built with combustible material, such as structured finance and inadequate supervision; a sudden rush for liquidity and fast deleveraging exacerbated by the practice of fair value accounting kept the fire running.

The innovation that best characterizes this crisis is the "originate and distribute" bank model, in which banks originate loans or purchase loans from specialized brokers to either sell them in the financial markets or transfer them to sponsored structured investment vehicles (SIV). Two serious problems arise with the practice of structured finance. The first regards the incentive of the originator to screen debtors when the loans are destined to be placed off balance sheet. Reputational considerations would suggest that the originator would not want to compromise its standards. However, the fact that regulators and accounting standards required little disclosure about unconsolidated off-balance sheet entities made these entities opaque to investors and lowered the cost of reputational loss to the sponsoring institution. To complicate matters, the ratings agencies were not up to the task of properly evaluating the new complex products. Errors in judgment were as glaring as assigning the same letter grade to a CDO and a corporate bond with sharply different default rates. ${ }^{3}$ The second concerns the contingency that the off-balance sheet entities may be reabsorbed by the sponsoring institution. Balance-sheet absorption can occur either because the sponsoring institution covers more than half of the trading losses of the sponsored SIV or because the sponsoring institution wants to prevent a downgrade of the SIV's credit risk (IMF 2008a, Box 2.6). At that point, there is a reversal of the intended benefits of "originate and distribute;" namely, risk returns home and regulatory capital rises. The investor, having finally gained transparency in the transaction, may judge correctly that the sponsoring bank is overleveraged and demands for it a higher required return on capital; this translates into a spot drop of the share price of the consolidated bank.

\footnotetext{
${ }^{3}$ Calomiris (2007, p. 19) quotes from the Bloomberg Market of July, 2007 that CDOs rated Baa by Moody suffered fiveyear default rates of 24 percent, whereas corporate bonds with the same rating had default rates of 2.2 percent.
} 


\section{Liquidity rush and risk repricing}

The liquidity crisis exploded in the interbank market in August of 2007 with a rise in spreads of threemonth interbank lending rates relative to policy rates and yields on three-month Treasury bills. The socalled US TED -the difference between the three-month Libor interest rate and the three-month U.S. Treasury bill- under ordinary times is contained within 20 to 30 basis points. At the peak of the Mexican crisis of 1994-95 and the South-East Asian financial crisis of 1997, it rose to approximately 60 basis points. In the Gulf War and the crisis of Long Term Capital Management, it peaked at approximately 120 basis points. During the entire subprime crisis, TED has moved to uncharted territory. Figure 1 plots TED values for three areas of the world: the United States, Europe and the Pacific region. The US TED, from 15 September (the day when Lehman declared bankruptcy) to 14 October 2008, averaged over 300 basis points and reached an all-time peak of 464 basis points on 10 October 2008, the Friday that ended a historic week of panic selling in the equity markets. A similar story holds for the TED of the large European countries and Hong Kong. Japan, on the other, stands as a country of moderate risk.

\section{[Insert Figure 1 here]}

The markets were gripped by fears of credit and liquidity risks, two risks distinguishable in theory but not in practice (IMF 2008b, pp. 78-81). The fact that the massive injections of monetary base by central banks were ineffective in containing the spreads in the interbank market is consistent with the view that market participants were worried of large credit risks and adverse selection and that they could not separate liquidity from credit concerns. Spreads relative to yields on government bonds shot up across all maturities, short and long; see IMF (2008b, Figures 4 and 5, pp. 172-3). ${ }^{4}$ The switch in the public's degree of risk aversion was justified by the mounting difficulty of gathering reliable

\footnotetext{
${ }^{4}$ See Mishkin (1991) for historical evidence from the $19^{\text {th }}$ and $20^{\text {th }}$ century US panics.
} 
information on opaque clients in times of distress. Confronted with more uncertainty in assessing the true credit status of relatively opaque borrowers, creditors had no better method than applying higher interest rates to entire classes of borrowers. The fog shrouding banks' balance sheets and the financial markets was reinforced by opaque accounting practices. To illustrate, according to reported accounting data, the US banking system did not yet appear severely undercapitalized: at the end of 2008, the ratio of Tier 1 or core capital to risk-weighted assets was 17.4 percent for small banks, 12.3 percent for intermediate banks, and 9.4 percent for large banks (Fratianni and Marchionne 2009). These ratios are way above the benchmark of 4 percent. Yet, it was widely acknowledged that banks were severely undercapitalized. Undercapitalization has been the biggest stumbling block to the resolution of the financial crisis.

The biggest impact of the subprime has occurred through the re-pricing of risk across a variety of assets and the shrinking of balance sheets. Spillovers across markets and the subsequent process of deleveraging are the standard prediction of the CBB hypothesis. Deleveraging can be done either by selling assets or by recapitalizing. Recapitalization was aggressively pursued from the second half of 2007 through September 2008, when global banks raised $\$ 430$ billion of fresh capital (IMF 2008b, p. 22). Then, recapitalization became increasingly difficult, and leverage had to be lowered by selling assets in illiquid markets. Thus, in the absence of fresh capital and without significant profits to retire debt in the short run, the deleveraging process necessarily implies distress sales and falling asset values (Adrian and Shin 2008, Figure 2.5). The shorter the horizon over which deleveraging occurs, the more dramatic is the implosion of asset prices. The rapidly rising risk aversion of the public, fed by bad news and the thick fog of asymmetric information, was pushing financial institutions to compress leverage quickly. Fair value accounting aggravated the problem through its pro-cyclical bias. Lower accounting asset prices impact negatively on regulatory capital and may have pushed bankers to engage in liquidation sales that further depressed asset prices. 


\section{Markets' reaction}

To have an appreciation of the extent of the financial maelstrom, we need to turn to market data. For this purpose, we collected equity prices for a sample of banks from three areas of the world: the United States, Western Europe, and the Pacific region. The actual list, shown in the Appendix, includes 45 US banks, 49 banks from 14 different Western European countries, and 26 banks from three different Pacific region countries. ${ }^{5}$ The listed banks tend to be large and thus capable of engaging in complex structured finance. We provide three sets of descriptive statistics. The first, displayed in Figure 2, are market capitalization values for the three bank-area aggregates. The second, displayed in Figure 3, are holding-period dollar rates of return, again for the three bank-area aggregates. The third, shown in Table 1, provides rates of return, both in local currency and in dollars, for banks aggregated at the country level. The sample period goes from 31 July 2007, our benchmark of pre-crisis date, to 31 July 2009, our last observation. To simplify the presentation, we have taken a few benchmark dates in computing market capitalization and rates of return: the end of 2007, the end of the first and second quarter of 2008, 14 September 2008, the end of 2008, 6 March 2009 and the final observation of 31 July 2009. Some dates, such as quarter ends, are arbitrary but serve the purpose of underscoring the time evolution of the crisis. The 14 September 2008 is significant because is the day before Lehman Brothers filed for Chapter 11 bankruptcy protection, an event widely believed to have represented a watershed in the crisis. The 6 March 2009 was selected because it is the bottom of bank stock declines. To save space, Table 1 considers only three periods: the first phase of the crisis from 31 July 2007 to pre-Lehman's failure, the expanded phase of the crisis until 6 March 2009, and a further expanded phase including a modest recovery that goes up to our last observation 31 July 2009.

\section{[Insert Figures 2 and 3 and Table 1, here]}

\footnotetext{
${ }^{5}$ Only the largest listed banks are included. For Ireland, Norway, and Switzerland, we have only one bank each (see Appendix).
} 
Over the period from 31 July 2007 to 6 March 2009, the crisis has destroyed $\$ 3.23$ billion of market values in our sample of banks. European banks were hit the hardest with a 75 percent decline, the Pacific banks were hit the mildest with a 48 percent decline, and US banks fared in the middle with a 68 percent decline; see Figure 1. The decline, furthermore, was at least twice as large after September 14, 2009 than in the previous sub-period. This is quite apparent from the holding-period rates of return shown in Figure 2, and corroborates the view that the Lehman failure was perceived by the market as a critical event.

Table 1 compares rates of return at the national level, using both local-currency and dollar returns. Dollar returns are the sum of local-currency returns, the rate of dollar depreciation (or appreciation if negative) and the interaction between these two terms. The dollar depreciated relative to most currencies in the pre-Lehman period, appreciated in the first part of the post-Lehman period and then depreciated again in May of 2009. Take bank stocks of the euro area. In the pre-Lehman period, rates of return averaged -59 percent, over a range comprised between -42 percent for Austria and -92 percent for Portugal. Banks from France, Germany, Ireland and Portugal did worse than banks from Austria, Greece, Italy, and Spain. In the post-Lehman period, the euro average rate of return fell by an astounding -213 percent, over a range comprised between -102 percent for Spain and -404 percent for Ireland. Austrian, Belgian, German and Irish banks did much worse than French and Southern European banks. As we have already remarked in connection with dollar valuation, European bank stocks suffered the most, Pacific region bank stocks the least, and US bank stocks were in the middle. For most countries, but not for the United Kingdom, Norway and Sweden, the differences between local-currency returns and dollar returns were of a small order of magnitude.

This massive destruction of market value can be attributed only in part to deteriorating fundamentals. As predicted by the CBB hypothesis, the crisis made investors much more risk averse. To illustrate the extent of this shift in risk aversion, Figure 4 plots the distribution of price-to-earnings 
ratios computed over 4,000 US equities for the year 2007 and 2008 (Trzcinka 2009). ${ }^{6}$ The 2008 distribution shifts sharply to the left of the 2007 distribution: the mean tumbles from 40.8 to 18.9 , the $10^{\text {th }}$ percentile from 10.4 to 3 , the $90^{\text {th }}$ percentile from 62 to 29.5 . Across a very broad range of US equities, investors were valuing a unit of 2008 earnings with a price multiple that was less than one half the price multiple accorded to 2007 earnings. In sum, rising risk aversion magnified the effect of deteriorating fundamentals on bank stocks.

[Insert Figure 4, here]

\section{GOVERNMENT RESCUE PLANS}

The rescue of several large financial institutions in the United States and in Europe was sparked by the migration of liquidity risk from banks to finance and followed the rapidly expanding role of government as a market maker of last resort to support not only big banking but also big finance. The list of large failed institutions is long. After the merger of Bear Stearns with JPMorgan Chase \& Co., financed with a \$29 billion loan by the Fed of New York, the US government gave an explicit and massive guarantee to the liabilities of Fannie Mae and Freddie Mac that held or guaranteed at the time approximately \$5,200 billion of mortgages. An Asset Guarantee Program was launched in the last few days of the Bush Administration. The original October 2008 bailout proposal of Treasury Secretary Paulson, discussed below, excluded a guarantee program, but Congress pushed for its inclusion because it was concerned with the expenditure implications. Debt and asset guaranty are politically attractive because governments do not have to argue the case and request funds from Congress or Parliament. They also entail smaller current costs than the expected present-value contingent cost, suggesting that government gambles for a possible resurrection of the banking system. This strategy was a defining characteristic of both the US S\&L crisis of the Eighties and the long Japanese crisis of

\footnotetext{
${ }^{6}$ There are 4,363 firms in the 2007 sample and 4,010 in the 2008 sample.
} 
the Nineties; and it was responsible for transforming "a relatively small cost into a staggeringly large one" (Glauber 2000, p. 102). ${ }^{7}$

The failure of Lehman Brothers on September 15th was the high point of the financial crisis: credit default swap premia on a sample of North American and European commercial and investment banks, in fact, peaked on that day (BIS 2009, Annual Report, Graph III.1, p. 38). The following day AIG, the enormous international insurance company, was bailed out by the US Treasury. ${ }^{8}$ On September 19th, the US Treasury announced a temporary guaranty program of up to $\$ 50$ billion for money market mutual funds. On September 26th, the FDIC closed the activities of Washington Mutual, making it the largest bank failure to date. On September 29th, the UK government nationalized Bradford and Bingley, a large UK mortgage lender. On September 30th, Fortis received emergency funding from the governments of Belgium, the Netherlands and Luxembourg. On October 5th, the German government extended guarantees to Hypo Real Estate Bank as part of a private takeover.

In the month of October, government interventions became less ad-hoc and more directed at addressing systemic problems. On October 3rd, the United States established the Troubled Asset Relief Program (TARP), authorizing the US government to purchase sub-standard illiquid assets up to an

\footnotetext{
${ }^{7}$ The most egregious error in the S\&L crisis was for regulators to wish for better times (Kane 1989, ch. 3). The Federal Savings and Loan Insurance Corporation permitted zombie thrifts to survive. To be sure, politicians were pressured by zombie thrifts, but, at the core, the problem lied in a weak principal-agent relationship. The public-taxpayer, the ultimate principal, was an unwary victim of the larger costs associated with delaying the closing of insolvent thrifts. Both the politician, the agent of the public, and the regulator, the agent of the politicians, were aided in their obfuscation strategy by the limitations of an accounting system that ignored the costs of contingent commitments like tax forgiveness and federal guarantees. Similar errors were repeated in Japan almost a decade later (Friedman 2000). Japanese regulators and supporting politicians gambled for an unlikely resurrection of the banks and their clients. Japanese banks were encouraged to provide additional loans to money-losing companies, with the knowledge that regulators would not enforce capital adequacy rules. At the same time, by putting on hold the reform of the deposit insurance, "the government allowed even the worst banks to continue to attract financing and support their insolvent borrowers" (Hoshi and Kashyap 2004, p. 9).

${ }^{8}$ The Federal Reserve of New York was authorized to lend to AIG up to $\$ 85$ billion. An additional authorization of \$37.8 billion was approved on October $8^{\text {th }}$.
} 
amount of $\$ 700$ billion spread over three tranches. No sooner was the law approved than it became apparent that valuing sub-standard assets would be a serious problem: without a market, the government was likely to either overvalue "toxic" assets, thus penalizing taxpayers, or undervaluing them, thus penalizing potential sellers. Fortunately, there was language in the bill for the Treasury to use the alternative of recapitalizing banks. ${ }^{9}$ On October 8 th, the UK government revealed a $£ 500$ billion financial support program centered on the recapitalization of the banking system. Eight banks were identified for immediate recapitalization: Abbey, Barclays, HBOS, HSBC, Lloyds, Nationwide, Royal Bank of Scotland, and Standard Chartered. ${ }^{10}$ The program was seen as a nationalization scheme. Nationalization is fastest in stopping a crisis but is invasive and has adverse long-term consequences on the future efficiency of the banking system. Thus, it has a relatively small cost to the taxpayer in the short run but has a potentially big upside in the long run. This is the solution that Italy adopted in the Thirties (Fratianni and Spinelli 2001, pp. 316-321). It took fifty years before the bulk of the Italian banking system was again privatized. Equity funding is a partial nationalization. It is less credible than full nationalization as a commitment mechanism to restore banks to long-term viability; it is more expensive than nationalization in the short run, but makes it is easier and less costly for government to disengage from banking once the crisis is over.

On October 14th, Treasury Secretary Paulson changed tack and adopted the UK model, although it fell short of complete nationalization. ${ }^{11}$ The new program was relabeled TARP Capital Purchase Program and permitted eligible institutions to apply for preferred stocks owned by the US

\footnotetext{
${ }^{9}$ Interestingly enough, the recapitalization strategy was employed by the Reconstruction Finance Corporation (19321953), a fact that seemed to have been completely ignored by the first version of TARP.

10 These institutions committed to increase capital by $£ 25$ billion. Government would inject $£ 50$ billion in the form of preference shares and with conditions such as limits on executive compensation, dividend policies and commitment to support lending to small business and home buyers. Furthermore, $£ 250$ billion would be made available to eligible institutions to guarantee new short and medium term debt issuance. To obtain these guarantees the eligible institutions had to raise Tier 1 capital to the level deemed appropriate by government.

${ }^{11}$ The official announcement that Treasury would no longer purchase illiquid mortgage-related assets was made on November 12.
} 
Treasury up to an aggregate of $\$ 250$ billion. $^{12}$ On October 16 th, UBS received a capital injection from the Swiss government. On October 19th, there was news of a capital injection in ING by the Dutch government. On the same day, the South Korean government announced a $\$ 130$ billion financial rescue plan. On October 20th, it was Sweden's turn to announce its own rescue package worth $\$ 205$ billion. On October 28th, Belgian KBC and Dutch Aegon were targeted for capital injections by their respective governments. On November $28^{\text {th }}$, the Italian government unveiled a plan of issuing government subordinated bonds to fund targeted banks. Under this scheme, the Italian Treasury would borrow from the markets and lend to the banks at a much higher interest rate. ${ }^{13}$

Additional measures were taken in 2009 , this time with more attention being paid in relieving banks of bad assets. The creation of a bad-asset bank worked well for the Nordic countries, especially for Sweden, in resolving their financial crisis of the early Nineties. Governments intervened early and decisively, and not only bought toxic assets but managed them. In Sweden, the crisis erupted in the early part of 1992; shortly after that the government purchased two large failing banks (Nordbanken and Gotabanken) and created two asset-management institutions (Securum and Retriva) to acquire and manage bad loans (Drees and Pazarbasioglu, 1998). Altogether, the government committed less than $\$ 10$ billion to rescue the banking system. ${ }^{14}$ The crisis was relatively short-lived. However, this episode suggests that certain conditions were critical in making the bad-asset bank model successful: a transparent political system, a well delineated plan, uncorrupt bank practices, a broad consensus in the population to support banks, and a competent management to

\footnotetext{
12 The preferred shares would pay a cumulative dividend rate of 5 percent for the first five years and 9 percent subsequently. Furthermore, Treasury would receive warrants to purchase common stocks for an aggregate market price of 15 percent of the senior preferred shares; the exercise price of the warrants would be the market price of the common stock at the time of issuance calculated on a 20-trading day trailing average. The program had restrictions on dividend payment and executive salary. Nine large financial institutions declared their intentions to subscribe to this facility for an amount of $\$ 125$ billion; the announcement is dated October 28, 2008.

${ }_{13}^{13}$ To further limit risk for Treasury, the requesting banks would be subject to a stress test performed by the Banca d'Italia.

${ }^{14}$ The cost of the rescue plans, net of liquidation of assets and including appreciation in the value of government shares, was close to zero for Sweden and Norway and 5.3 percent of GDP for Finland; see Anderson (2009).
} 
run the new institutions (Ingves and Lind 1996). These conditions were not present during the deep and long Japanese financial crisis of the Nineties and the bank-asset model failed despite repeated attempts. $^{15}$

The purchase of banks' low-quality assets was announced in a new US plan by Treasury Secretary Timothy Geithner on February $10^{\text {th }}$, with details unveiled on March $23^{\text {rd }}$. In addition to government buying convertible preferred stock in qualified banks, the plan added a Public-Private Investment Program (PPIP) aimed at relieving banks of legacy assets. ${ }^{16}$ PPIP would be funded by government and private financial institutions with each putting up equity of $\$ 75$ to $\$ 100$ billion. The equity would be leveraged with interest-free non-recourse loans (i.e., pledged by collateral, but without any personal liability for the borrower) by the FDIC and the Fed up to a ratio of 6 to 1 . PPIP became quickly controversial. Paul Krugman (23 March 2009), from the pages of the New York Times, was quick in declaring, politely, that the Administration was lying on the claim that PPIP involved no taxpayer's subsidy. Jeffrey Sachs (25 March 2009) titled his article in VoxEU "Will Geithner and Summers succeed in raiding the FDIC and Fed?" Joseph Stiglitz (31 March 2009), in the New York Times, labeled the PPIP "Obama's Ersatz capitalism," the privatizing of gains and socializing of losses. Peyton Young (1 April 2009), in the Financial Times, thought the PPIP would be the taxpayer's curse, the parallel to the winner's curse in auctions. The common element underlying these reactions was that the Plan would entail a massive and unnecessary wealth transfer from taxpayers to the financial markets. It was deemed unnecessary because a direct government transfer to the banks would

\footnotetext{
${ }^{15}$ Four attempts were made in setting up bad-asset banks: the first in 1992, the second in 1995, the third in 1995 and the last (the Industrial Revitalization Corporation of Japan) in 2003. It should be noted that there are differences between the Nordic and Japanese crises, such as: the economic size of the Nordic countries was and is significantly smaller than Japan's; Nordic countries were foreign net debtors, whereas Japan was a foreign net creditor; and liberalization occurred way before the crisis in Sweden and Finland, helping these countries to clean up bad loans from their balance sheets through a more efficient financial market, whereas financial deregulation was a reaction to the crisis in Japan.

${ }^{16}$ The Geithner Plan also added a compulsory stress test for the 19 largest US bank holding companies. The results of this test were unveiled in early May and found that 9 of the 19 banks had adequate capital, while the remaining 10 had to add $\$ 75$ billion of fresh capital.
} 
be cheaper in rescuing the banks. This is because private investors would make extraordinary returns financed by government. Bids would rise through competition until returns would become "normal" or even zero. But as the price of assets rises, the transfer from taxpayers to banks would also rise. In essence, taxpayers would do worse than with a direct government transfer to banks. Yet, the Plan had to be seen from a political economy angle. Its "clever, complex and nontransparent" features -using Stiglitz' words- packed great political value. Like guarantees, it obscured the true cost of government intervention and raised the probability of its acceptance among the public.

This potted history of government interventions in the financial markets is bound to be unfinished. At the time of writing, other governments, such as those of Germany and Spain, are either in the process or in the planning stage of launching new rescue facilities.

\section{Estimates of government commitments and outlays}

We present three sets of aggregate data on government rescue plans. The first estimate is due to Mediobanca and was posted on its Website at the end of February of 2009; see Table 2. It refers to actual interventions by the United States and 10 European governments to support their banking systems. ${ }^{17}$ The second estimate comes from a study by the staff of the Bank of International Settlements and the Banca d'Italia (for short BIS-BdI) with a cut-out date for the data of 10 June 2009 (Panetta et al. 2009, Table 1.2 p. 9); see Table 3. It differs from Mediobanca's estimate in that it distinguishes between commitments and actual outlays, adds (relative to Table 2) three non European countries but includes a smaller set of European countries. ${ }^{18}$ The third estimate, shown in Table 4, is

\footnotetext{
17 The 10 European countries are Austria, Belgium, France, Germany, Ireland, Iceland, Luxembourg, Netherlands, Switzerland and the United Kingdom. Italy is excluded because it committed an unspecified amount of funds without incurring any expenditure.

${ }^{18}$ The added non European countries are Australia, Canada and Japan. As to the European countries, Italy and Spain were and Austria, Belgium, Ireland, Iceland, and Luxembourg were dropped.
} 
from BNP Paribas (2009) and is dated 1 June 2009: it has the broadest country coverage but is limited only to commitments.

According to Mediobanca's estimates, as of February 2009 the sampled 11 governments had spent $\$ 633$ billion in supporting their banking systems, of which 62 percent in the form of equity funding, 23 percent in debt guaranty, 7 percent in the purchase of bad assets, 5 percent in nationalization, and 3 percent in convertible bonds. The largest interventions were effected by the United States, Germany, the Netherlands and the United Kingdom. According to the BIS-BdI study, as of 10 June 2009, the (differently) sampled 11 governments had made commitments for approximately $€ 5,000$ billion and actual outlays for $€ 2,000$ billion. The value of total guarantees appears to be greatly understated. Just the guarantee commitment of the US government to Fannie Mae and Freddie Mac, as we have seen, exceeds $\$ 5,000$ billion. ${ }^{19}$ Six of the 11 countries are covered by the two estimates. As one would expect, the passage of time has meant more governments' interventions in the banking system. The biggest change refers to the United States, which has moved from $\$ 278$ billion in February to $€ 825$ billion in June, and the United Kingdom which has moved from $\$ 63$ billion to $€ 690$ billion. The increases are more contained for France, the Netherlands and Switzerland. The BIS-BdI study underscores the prevalence of guarantees ( 83 percent of total commitments and 78 percent of outlays) over capital injections (14 and 19 percent, respectively) and asset purchases ( 3 percent for both commitments and outlays). The BNP Paribas estimate covers 14 EMU countries, five non-EMU European countries, Australia, Canada, Japan, Qatar, Saudi Arabia, South Korea, UAE and the United States. Total commitments amount to $€ 5,700$ billion, of which 34 per cent in the United States, 34 per cent in the EMU countries, and 19 percent in the United Kingdom.

\footnotetext{
${ }^{19}$ At an exchange rate of of $\$ 1.3=€ 1$, it would amount to $€ 3,846$.
} 
In sum, the policy response to the subprime crisis started in earnest after Lehman's failure in mid September 2008, accelerated after February 2009, and has become very large at the time of writing (September 2009). The narrative and the data have underscored that governments have relied on a portfolio of intervention tools, but the biggest commitments and outlays have been in the form of debt and asset guarantees, while purchases of bad assets have been very limited. In what follows, we evaluate the rescue plans from the viewpoint of financial markets, that is how bank stock prices have reacted to the commitment news of supporting banks.

[Insert Tables 2-4, here]

\section{ESTIMATING THE EFFECTS OF GOVERNMENT RESCUE PLANS}

In this section, we employ event study methodology to estimate markets' reaction to the announcements of government interventions. The underlying hypothesis is that both the announcement of a rescue plan is credible if it raises the survivability and rates of return of participating banks. Therefore, we can test the effects of rescue plans by computing cumulative abnormal returns (CAR) of participating banks around a window that includes announcement dates. For the actual test, we will use the same sample of banks in Table 1; see Appendix. Estimates of alpha, the risk free rate, and beta, the market risk parameter, from the capital asset price model will be based on daily market return observations of three sample periods: the first from 31 July 2007 to 14 September 2008 (the day before Lehman Brothers' failure), the second from 15 September 2008 to 6 March 2009 (the bottom of the market) and the third from 7 March 2009 to our last available observation of 31 July 2009.

The events are of two types. The first is an announcement that the government will intervene to protect the banking system (for brevity, general announcement). Our main data sources are Mediobanca, BIS-BdI, and BNP Paribus, but we have also used information from DLA Piper, the International Capital Market Association and websites of Ministries of Finance or Treasury. For the 18 
countries represented in our data set, there are 37 general announcements, of which the greatest number pertains to capital injections; see Table 5. The second is an announcement that a specific bank will receive government support (for brevity, specific announcement). We have 63 specific announcements affecting 43 of the 120 banks in our sample, of which 4 pertain to asset purchase and guarantees, 8 to debt guarantees, and 51 to capital injection; see Table 6. A few banks, such as Bank of America and Hypo Real Estate, have multiple announcements. The 43 banks with specific announcements represent half of the countries in our sample. ${ }^{20}$ Seventy seven banks from the other half of the countries have no announcement, in particular those from the Pacific area.

\section{[Insert Tables 5 and 6, here]}

We propose three separate tests within the broad event study methodology. The first aims at uncovering the overall impact on banks' equity valuation of general and specific announcements. The

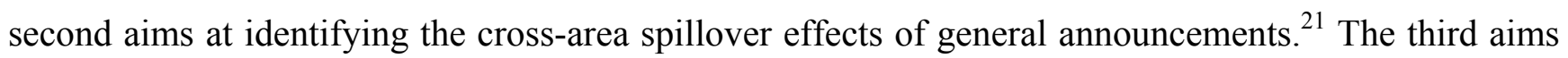
at uncovering the cross-bank spillover effects of specific announcements.

The first test uses the entire panel of 120 banks, 37 general announcements and 63 specific announcements. Daily rates of returns on bank stock $i$ of country $j$ at time $t, R_{i j t}$, are regressed on an intercept capturing the risk-free rate of return and on the market rate of return, $R^{M}{ }_{j t}$, and two dummy event variables. The first dummy variable, $G_{j t}$, is equal to one during the event time window, $T$, around a general announcement, otherwise it is zero; the second dummy variable, $S_{i t}$, is equal to one in the time window $T$ around a specific announcement. We also break down $G$ and $S$ by the different intervention types discussed above, such as asset purchases, capital injections, and debt guarantees. We assume that a general announcement is more complex than a specific announcement and requires

\footnotetext{
${ }^{20}$ The nine countries are Austria, Belgium, France, Germany, Ireland, Italy, Netherlands, UK, and US.

${ }^{21}$ We cannot determine cross-country spillover effects because of the collinearity of many general announcements across countries.
} 
longer time for the market to process it; in addition, it is easier for the markets to get wind of a general announcement than of a specific one. For this reason, we apply different windows to the two types of announcements: G's window is seven days and is comprised between three working days before and after the announcement, whereas $S$ 's window is five days. The test is formalized in equation (1):

$$
R_{i j t}=\alpha+\beta \cdot R_{j t}^{M}+\gamma \cdot G_{j t}+\delta \cdot S_{i t}+u_{i j t}
$$

where $u$ denotes a well-behaved error term and $G$ and $S$ become dummy vector when we disaggregate by intervention type. ${ }^{22}$ Markets' reaction to announcements are captured by $\gamma$ and $\delta$ : within the time window $T$, CAR is predicted to be higher than returns in other periods. Since the error of the regression must be zero on average, the null hypothesis is that CAR within $T$ must also be zero. A rejection of the null hypothesis corroborates the presence of abnormal rates of return. In our one-step formulation of the event study regression (1), the positive impact of news of a government intervention on rates of return is captured by CAR, which is equal to the sum of the estimates of parameters $\gamma$ and $\delta$ multiplied by $T$; see Meulbroek (1992).

The second test uses bank data from each of the 3 areas, as in (2):

$$
R_{i t, j}=\alpha_{j}+\beta_{j} \cdot R_{t, j}^{M}+\gamma_{j} \cdot G_{t, j}+\delta_{j} \cdot S_{i t, j}+\sum_{k=1}^{3} \theta_{k, j} \cdot X G_{i t k, j}+u_{i t, j} \cdot \quad j=1,2,3
$$

There are two differences with respect to equation (1). The first is that coefficients are now denoted with a subscript " $j$ " to indicate that they are area specific. The second is that (2) adds three area

${ }^{22}$ In this case, the extended formulation is:

$$
R_{i j t}=\alpha+\beta \cdot R_{j t}^{M}+\sum_{k=1}^{3}\left(\gamma_{k} \cdot G_{k j t}+\delta_{k} \cdot S_{k i t}\right)+u_{i j t},
$$

where $\mathrm{k}=1$ indicates asset guarantees and purchase, $\mathrm{k}=2$ capital injection, and $\mathrm{k}=3$ debt guarantees. 
announcement dummies, $X G_{k}$. Each $X G_{k, j}$ is equal to one during the event time window around the general announcement from a country of area $k$, except for those from the country of bank $i$; for example, $X G_{3,1}$ captures the general announcement effect of area 3 (say, Pacific) on area 1 (say, USA). Note that $X G_{j, j}$ captures cross-area general announcement effects from the same area is not collinear to general announcement $G_{j}{ }^{23}$ The estimate of $\theta_{k, j}$ times $T$ measures the spillover effect of general announcement from area $k$ on CAR of area $j$ 's banks.

The third and final test focuses on the cross-bank spillover effects of specific announcements. The motivation for this experiment is that during a crisis markets are shrouded in a fog of ignorance about the true extent of banks' difficulties. The news that one large bank will be receiving government support sends two separate signals: the first is that other banks of similar size are likely to be in the same predicament and the second is that if government saves a large bank is also likely to save another. The failure of Lehman's Brothers shook the markets exactly because it was a glaring exception to the too-big-to-fail principle. ${ }^{24}$ It is doubtful that Treasury Secretary Paulson would have taken the same decision had he anticipated the markets' reaction. Given the limitations of our data, we restrict the test to the seven largest US banks: Bank of America, Citigroup, J.P. Morgan, Wells Fargo, Goldman Sachs, American Express, and Morgan Stanley. We selected these banks on the base of the average market capitalization of the pre-crisis period from 31 July 2007 to 14 August 2008. Banks in our sample represent more than 60 percent of the US bank market capitalization, 100 percent of asset guarantees and purchases, 100 percent of debt guarantees, and 90 percent of capital injections. The formulation of this test is given by equation (3):

\footnotetext{
${ }^{23}$ For example, $X G_{3,3}$ captures the general announcement effect of $n-1$ countries of area 3 (e.g., Australia and Honk-Kong) on other $n^{\text {th }}$ country of the same area (say, Japan).

${ }^{24}$ For evidence of the too-big-to-fail principle, see O'Hara and Shaw (1990).
} 


$$
R_{t, i}=\alpha_{i}+\beta_{i} \cdot R_{t, i}^{M}+\gamma_{i} \cdot G_{t, i}+\delta_{i} \cdot S_{i t, i}+\sum_{\substack{k=1 \\(k \neq i)}}^{7} \lambda_{k, i} \cdot X S_{t k, i}+u_{t, i}, \quad i=1, \ldots, 7
$$

where subscript " $\mathrm{j}$ " was dropped because all i banks are located in the same country. $X S_{k, i}$ indicates the cross-specific announcement of bank $k$ on bank $i$. Note that the own $S$ is equal to the cross-specific announcement when $i=k$. Coefficent $\gamma_{i}$ captures the effect of US $G, \delta_{i}$ the effect of $S$ for the $i^{\text {th }}$ bank (say, Bank of America), $\lambda_{\mathrm{k} \neq \mathrm{i}}$ the effect of $S$ for the $k^{\text {th }}$ bank (say, Citigroup, J.P. Morgan, Wells Fargo, Goldman Sachs, American Express, and Morgan Stanley).

\section{$\underline{\text { Findings }}$}

Table 7 shows estimates of equation (1) for the period spanning from 31 July 2007 to 31 July 2009 and the three sub-periods we have already used for Table 1: the pre-crisis from 31 July 2007 to 14 September 2008, the crisis from 15 September 2008 to 6 March 2009, and the post-crisis from 7 March 2009 to 31 July 2009. We have 34,354 observations in the first period, 14,697 in the second and 12,416 in the third. We test equation (1) by first aggregating all types of general and specific announcements and then using the three specific categories of asset purchase, capital injections, and debt guarantees (see equation (1b); e.g, $G_{1}=$ general announcement of asset purchase, $S_{2}=$ specific announcement of capital injection). We recall that $G$ has a seven-day window and $S$ a five-day window. We did experiment with different window lengths: results tend weaken as the window is enlarged, in particular for specific announcements. The bulk of the announcements occurs in the second period; see Tables 5 and 6 . The panel is estimated with fixed country effects, a specification 
that is not rejected by the Hausman (1978). ${ }^{25}$ In addition to the variables indicated on the right-hand side of equation (1), we have added the logarithmic value of bank capitalization expressed in dollars. In fact, bank size turns out to have positive and statistically significant effects in the first and second periods.

The key finding of Table 7 is that announcements, general as well as specific, have a statistically significant and economically relevant impact on banks' rates of return. Over the entire two-year period, CAR were almost 5 percentage points higher than normal returns for general announcements and 6 percentage points lower than normal returns for specific announcements. The signs of the coefficients reflect differences in the way markets evaluate the two types of announcements. General announcements are taken as signals that governments want to protect the banking systems. The banking industry, as a whole, receives support and rates of return to shareholders rise "abnormally" over the announcement window. Specific announcements are more problematic for the markets. During times of relative transparency, when markets face stable information flows and price with relative efficiency banks' future net cash flows, $S$ is evaluated as a boost to shareholders' return. On the other hand, in the fog of a financial crisis, when markets are extremely uncertain about the quality of the assets they have to evaluate, $S$ is taken as a revelation of partially unknown troubles; CAR may turn to be negative. On this point, it is worth mentioning that particularly hectic activities took place in the first half of October 2008, when governments intervened on a big scale to stabilize their banking systems; see Figure 5. Over a two-week period, policy makers first tried to purchase or

\footnotetext{
${ }^{25}$ The Hausman (1978) specification test uses the statistic $H=N\left(\beta_{F E}-\beta_{R E}\right)^{\prime} \operatorname{Var}\left(\beta_{F E}-\beta_{R E}\right)^{-1}\left(\beta_{F E}-\beta_{R E}\right)$ to compare fixed effects with random effects, where $N=$ number of observations, $\beta_{F E}$ and $\beta_{R E}$ are respectively the vector of coefficients in the FE and RE model, and Var(.) indicates the variance-covariance operator; $H$ has a chi-squared distribution. In Table 7, except for the last column, the null hypothesis that the estimated coefficients from the fixed- effect model is not systematically different from the coefficients of the random-variable model is rejected. In this case, that is under the alternative hypothesis, the random-effect model is inconsistent, where the fixed-effect model is. In the last column, the Hausman test fails to meet asymptotic assumptions.
} 
guarantee assets, then moved to inject capital into banks, and finally decided to guarantee bank debts. The fact that three different strategies were adopted in such a brief time span underscores the state of confusion, if not outright panic, enshrouding government decisions. Capital markets were extremely opaque in the immediate wake of Lehman's failure

Differences in the information environment appear to be corroborated by the CAR pattern in the three sub-periods: $S$ has a positive impact on $R$ in the pre-crisis sub-period, when announcements are few and markets have relative confidence in the "normal" information flow; but the opposite takes place in the turbulent crisis sub-period when announcements are the order of the day and markets mistrust the "normal" information flow. These results appear consistent with the observed reluctance of individual institutions to come forth with requests for public assistance. Fear of being identified as a "bad apple" was also the reason why some banks were reticent, during 2008, to apply at central banks for emergency lending.

The key finding of the second group of estimates of Table 7 is that the markets do not distinguish between the relative efficacy of different types of announcements. In fact, we cannot reject the null hypothesis that $G_{1}, G_{2}, G_{3}$, and similarly for $S$, exert equivalent impacts on $R .^{26}$ These results suggest two policy implications. The first is that, during a big financial crisis, markets value timely and big actions without little regard to refinements on the type of actions undertaken. The different longrun consequences of different interventions are ignored. The similitude with a war is compelling. Like in a war, participants in a financial crisis want to survive: planning horizons are shortened and considerations that are taken seriously under normal circumstances are instead relegated to minor roles in a crisis. This pattern is consistent with the lessons from Nordic and Japanese banking crises: timely

\footnotetext{
${ }^{26}$ The Wald test shows that the announcements, taken as a whole, have a non-zero impact on rates of return for the entire period and the crisis sub-period. The $\mathrm{F}$ test on $G$ and $S$ pairs shows that effect similarity cannot be rejected. For the precrisis period, the $\mathrm{F}$ test cannot be done because of the scarcity of announcements.
} 
and big public interventions solved successfully the crisis in Sweden, whereas untimely and small government measures led to the lost Japanese decade. The second is that, given that different announcements produce equivalent effects, governments have incentives to gamble for opaque and "low-cost" guarantees of bank assets and debts rather than undertake more transparent and costly alternatives.

\section{[Insert Table 7 and Figure 5, here]}

Table 8 presents the results of equation (2), where our 120 banks have been divided into the three geographical groups of Figure 1: Europe, the Pacific area, and the United States. The motivation of the test is to unveil possible cross-area announcement effects. Thus, a bank in a given country will respond not only to its country's general announcement and its own specific announcement but also to the general announcements concerning other banks abroad. The key finding is that there are five statistically significant cross-area coefficients: with the exception of the cross-area Pacific $X G_{P A C I F I C}$ in the Pacific area regression and cross-area USA in the Europe regression, the remaining three show a negative impact on banks' returns. These negative values are consistent with a view that foreign rescue plans are perceived by home banks as a subsidy and, thus, giving a competitive advantage to foreign banks. However, in the Pacific area a subsidy to a given bank appears to benefit all other banks in the area. Note the "anomaly" of $\gamma<0$ and $\theta_{\text {USA }}>0$ (although marginally significant) in the Europe regression. We reran the regression, separately, only for UK banks and for Euro-area banks. This distinction is justified on two grounds. The first is that, as we have noted in our narrative of rescue plans, formal British capital injections were de-facto nationalizations that tend to be unfavorable to private shareholders. The second is that Euro-area banks enjoy the benefits of the euro and emergency lending by the European Central Bank. The two regressions confirm that the UK has a strong and dominant impact on the entire group of European banks, and that, if one controls for a common currency and a common central bank with lending-of-last resort power, we obtain again that the own $G$ 
effect on bank returns is positive and statistically significant, whereas the $X G_{U S A}$ effect vanishes. The economic relevance of the own $G$, is worth mentioning, is three times larger for US banks than for European and Pacific area banks, reflecting the more aggressive and extensive nature of US intervention plans.

Table 9 shows the estimates of equation (3), focusing on cross-bank spillover effects of specific announcements within a banking system. For the data, we select the top seven US banks by market capitalization as of 31 July 2007: Bank of America, Citigroup, JPMorgan Chase, Wells Fargo, Goldman Sachs, American Express Co. and Morgan Stanley. ${ }^{27}$ There are three statistically significant own $S$ effects: those of Bank of America and Goldman Sachs, which are consistent with reluctant borrowing behavior, and those of Wells Fargo, which indicate a big boost to shareholders. The Wells Fargo's announcement, furthermore, gives a big boost also to the shareholders of Bank of America, Citigroup and American Express. On the other hand, the announcement concerning Bank of America has a negative impact on $R$ of Citigroup; that of Citigroup has a negative impact on JP Morgan; and that of JPMorgan has a negative impact on American Express. What to make of these signs? We recall that an $S$ announcement may signal unexpected and unpriced financial difficulties; but it could also signal that if government saves a large bank it is also likely to save another at least just as big. Wells Fargo is the fourth largest bank. Based on the too-big-to-fail principle, the $S$ announcement for Wells Fargo would be interpreted that banks larger than Wells Fargo (Bank of America, Citigroup and JP Morgan) would also receive government support; hence, the cross-effect should be positive. But the positive impact of Well Fargo's announcement on American Express is not consistent with the rankings. Of course, it is plausible that American Express may be lower than Wells Fargo in market

\footnotetext{
${ }^{27}$ The top two institutions, Bank of America and Citigroup, had similar market capitalization (respectively \$213 and \$210 billion); JP Morgan was approximately three-quarters of their size, Wells Fargo and Goldman Sachs half of their size, and Express and Morgan Stanley one third of their size. Note that this selection is robust to different market valuations obtained at different dates.
} 
capitalization but higher in the degree of interconnectedness. Clearly, there is more to the story of too big to fail than sheer market capitalization.

In sum, the findings on equations (1) through (3) show that: general and specific announcements are priced by the market as CAR over the selected windows; general announcements tend to generate positive CAR and specific announcements negative CAR; general announcements exert cross-area spillovers but are perceived by the home-country banks as subsidies boosting the competitive advantage of foreign banks; and specific announcements exert spillovers on other banks.

[Insert Tables 8 and 9, here]

We have ignored the impact that monetary policy might have had on our tests. There are three possible channels for monetary policy to influence our regressions. The first is that it may affect the estimate of $\beta$ but not the estimates of $\gamma$ and $\delta$. Suppose that, by ignoring an expansive monetary policy, we have overestimated $\beta$. It follows that the $G$ effects would be underestimated. Thus, the test we have performed is biased against us. The second is that we ignore the impact of monetary policy at home and abroad. If those policies were idiosyncratic, there would be a distortion in our estimates of the $X G$ effects. But, the evidence suggests that monetary policies were expansive and coordinated after the failure of Lehman Brothers, implying that such a distortion does not arise. The third is that expansive monetary policies were positively correlated with expansive fiscal policies. Had we introduced a separate effect for monetary policy, the policy collinearity would have prevented us from detecting separate effects. In sum, to ignore monetary policy reactions to the crisis at the minimum should not affect our findings but it is likely to bias the test against us.

\section{SUMMARY AND CONCLUSIONS}

The great financial crisis of 2007-2009 had its roots in a credit boom that manifested itself in an extremely indebted US economy and in a high appetite for risk by investors. The collapse of the real 
estate market in 2006 and the high failure rates of subprime mortgages were the first symptom of a credit boom tuned to bust. These defaults spread the fire in a financial system that had become fragile as a result of several factors that are unique to this crisis: the transfer of assets from the balance sheets of banks to the markets, the creation of complex and opaque assets, the failure of ratings agencies to properly assess the risk of such assets, and the application of fair value accounting. To these novel factors, one must add the more standard failure of regulators and supervisors in spotting and correcting the emerging weaknesses.

Banks' undercapitalization has been the biggest stumbling block to the resolution of the financial crisis. From the end of July 2007 to 6 March 2009, our sample of 120 large US, Western European, and Pacific region banks lost \$3,232 billion of capitalization. European banks were hit the hardest; US banks were next. The bulk of the losses occurred after the failure of Lehman Brothers. This massive destruction of market value can be attributed only in part to deteriorating fundamentals. The financial crisis, not surprisingly, made investors much more risk averse. Based on US equities, investors were valuing, on average, a unit of 2008 earnings with a price multiple that was less than half the price multiple accorded to 2007 earnings. Rising risk aversion and deteriorating fundamentals reinforced each other in a brutal manner.

Banks' undercapitalization explains the persistence of the crisis and is the reason why governments continue to inject vast sums of public funds into banks. The first rescue plans started after Lehman's failure in mid September 2008 and were ad-hoc responses to specific negative events. In October of the same year, governments began to focus on systemic problems. We have shown quantitative summaries of both commitments and actual disbursements using alternative sources. Estimates, naturally, vary depending on country and time coverage. The two latest estimates -one by the BIS and the other by BNP Paribas- show that governments have committed aggregate sums in excess of $€ 5$ trillion to support their fragile banking systems and actually disbursed two-fifths of the 
committed funds. Both in absolute terms and in relation to the size of the economies, these interventions are extraordinarily large. We will have to wait for careful historical research to judge whether these interventions represent an all-time record. In addition to size, governments have employed a portfolio of intervention tools. The biggest commitments and outlays have been in the form of debt and asset guarantees, while purchases of bad assets have been limited. Political-economy considerations explain the high weight assigned to opaque and complex guarantees.

We found that general and specific announcements were priced by the markets as cumulative abnormal rates of return over the window periods. General announcements tend to be associated with positive abnormal returns and specific announcements with negative abnormal returns; general announcements exert cross-area spillovers but are perceived by the home-country banks as subsidies boosting the competitive advantage of foreign banks; and specific announcements exert spillovers on other banks. Our results were also sensitive to the information environment. Specific announcements tend to exert a positive impact on rates of return in the pre-crisis sub-period, when announcements are few and markets have relative confidence in the "normal" information flow. The opposite takes place in the turbulent crisis sub-period when announcements are the order of the day and markets mistrust the "normal" information flow. These results appear consistent with the observed reluctance of individual institutions to come forth with requests for public assistance. Fear of being identified as a "bad apple" was also the reason why some banks were reticent, during 2008, to apply at central banks for emergency lending.

The crisis is not likely to end until balance sheets will have expurgated toxic assets. Banks will not resume lending until balance sheets will have been cleansed and undercapitalization has been overcome. Banking systems remain fragile and additional government funds may be required to stabilize banks. Given that governments will have diminished resources, the greatest challenge may well be for politicians to convince an enraged public of the necessity of either injecting additional 
funds into the banking systems or undertaking outright nationalizations. In the 1990s, Japan paid very dearly, with a so-called lost decade, for delaying the recapitalization of the banking system. The financial crisis in Japan started in 1991 and was induced by a real estate boom pierced by a tightening of monetary policy. The crisis was most severe from the middle of 1994 to 1996; there was a reoccurrence in 1997. Legislation to use public funds to recapitalize the banks was passed only in February of 1998 (Nakaso 2001, p. 11). Public's hostility to use taxpayers' funds was the main reason for the costly delay.

We end with a cautionary note on the relationship between risk taking and moral hazard. Government rescue plans tend to consolidate the banking system in fewer and bigger players. This, in turn, raises the probability of invoking the too-big-to-fail policy. Given the strain on public finances created by the current crisis, it is now time to ask the question of when too-big-to-fail institutions become too big to be saved.

\section{References}

Adrian, T. and Shin, H.S. (2008), Liquidity and leverage, Federal Reserve Bank of New York; available online at http://www.newyorkfed.org/research/staff_reports/sr328.html.

Anderson, R.G. (2009), Resolving a Banking Crisis, the Nordic Way, Economic Synopses n. 10, Federal Reserve Bank of St. Louis.

Berger, A. and Udell, G. (2004), The institutional memory hypothesis and the procyclicality of bank lending behavior, Journal of Financial Intermediation, 12:458-495.

BNP Paribus (2009), To the rescue, Report of Market Economics, Interest Rate Strategy, Credit Strategy

Calomiris, C.W. (2007), Not (yet) a 'Minsky’ moment, Unpublished paper (October 5).

CNN Money (online); http://money.cnn.com/news/specials/storysupplement/bankbailout/.

Dell'Ariccia, G., Egan, D. and Laeven, L. (2008), Credit booms and lending standards: Evidence from the subprime mortgage market, International Monetary Fund, Working Paper WP/08/106.

Demyanyk, Y. and van Hemert, O. (forthcoming), Understanding the subprime mortgage crisis, Review of Financial Studies. 
DLA Piper (online); http://www.dlapiper.com/it/austria/news/detail.aspx?news=2858.

Federal Reserve Bank of St. Louis (online), The Financial Crisis. A Timeline of Events and Policy Actions; available online at http://timeline.stlouisfed.org/index.cfm?p=timeline\#.

International Capital Market Association (online); http://www.icmagroup.org/getdoc/d084024f-e70946e3-97a6-0b471db7a7ea/Responses-to-market-turbulence--Country-plans.aspx\#Australia.

Drees, B., and Pazarbasioglu, C. (1998), The Nordic Banking Crises: Pitfalls in Financial Liberalization?, Washington DC: IMF.

Fisher, I. (1933), The Debt Deflation Theory of Great Depressions, Econometrica 1; 337-57.

Fratianni, M. (2008), Financial crises, safety nets and regulation, Rivista Italiana degli Economisti, 2: 169-208.

Fratianni, M. and Marchionne, F. (2009), The role of banks in the subprime financial crisis, Review of Economic Conditions in Italy, 2009/1:11-48.

Fratianni, M. and Spinelli, F. (2001), Storia monetaria d'Italia: Lira e politica monetaria dall'Unità all'Unione Europea, Milano: Etas.

Friedman, B.M. (2000), Japan now and the United States then: Lessons from the parallels. In Ryoichi Mikitani and Adam S. Posen (eds). Japan's Financial Crisis and Its Parallels to U.S. Experience. Washington, DC, Institute for International Economics, 37-56.

Glauber, R.R. (2000), Discussions of the financial crisis. In Ryoichi Mikitani and Adam S. Posen (eds). Japan's Financial Crisis and Its Parallels to U.S. Experience. Washington, DC, Institute for International Economics, 101-105.

Gramlich, E.M. (2007), Booms and busts: The case of subprime mortgages. Paper presented at the synposium "Housing, Housing Finance, and Monetary Policy," organized by the Federal Reserve Bank of Kansas City, Jackson Hole, Wyoming, August 30-September 1, 2007; www.KansaCityFed.org.

Hoshi, T. and Kashyap, A.K. (2004), Japan's Financial Crisis and Economic Stagnation, Journal of Economic Perspectives, 18(1): 3-26.

Ingves, S. and Lind, G. (1996). The Management of the Bank Crisis-in Retrospect, Sveriges Riksbank Quarterly Review, 1: 5-18.

International Monetary Fund (2008a), Global financial stability report: Containing systemic risks and restoring financial soundness, April 2008. Washington, DC. 
International Monetary Fund (2008b), Global financial stability report: Financial stress and deleveraging, macrofinancial implications and policy, October 2008, Washington, DC.

Kane, E.J. (1989), The S\&L Insurance Mess: How did it Happen? Washington, D.C.: The Urban Institute Press.

Kindleberger, C.P. (1978 [2000]), Manias, Panics, and Crashes: A History of Financial Crises, $4^{\text {th }}$ edition, New York: Wiley.

Krugman, P. (23 March 2009), Geithner plan arithmetic, New York Times.

Meulbroek, L.K. (1992), An Empirical Analysis of Illegal Insider Trading, Journal of Finance 47(5):1661-1699.

Mitchell, W.C. (1913), Business Cycles. New York: Burt Franklin.

Minsky, H. (1977), A Theory of Systemic Fragility. In E. J. Altman and A. W. Sametz (eds). Financial Crises: Institutions and Markets in a Fragile Environment. New York. Wiley, 138-52.

Panetta, F., Faeh, T., Grande, G., Ho, C., King, M., Levy, A., Signoretti, F.M., Taboga, M. and Zaghini, A. (2009), An assessment of financial sector rescue programmes, BIS Paper, 48; http://www.bis.org/.

O'Hara, M. and Shaw W. (1990), Deposit Insurance and Wealth Effects: The Value of Being "Too Big to Fail”, The Journal of Finance, Vol. 45, No. 5 (Dec., 1990), pp. 1587-1600.

Sachs, J. (25 March 2009).Will Geithner and Summers succeed in raiding the FDIC and Fed?, VoxEU.org.

Snower, D.J. (20 May 2009) Redistribution through the Geithner Plan, VoxEU.org.

Stiglitz, J. (31 March 2009). Obama’s Ersatz capitalism, New York Times.

Young, P.. (1 April 2009). Why Geithner's plan is the taxpayers' curse, Financial Times.

Wallison, P. J. (2009). The true origins of this financial crisis, American Enterprise Institute for Public Policy Reseach, February; http://www.aei.org/publications/filter.all,pubID.29419/pub_detail.asp. 

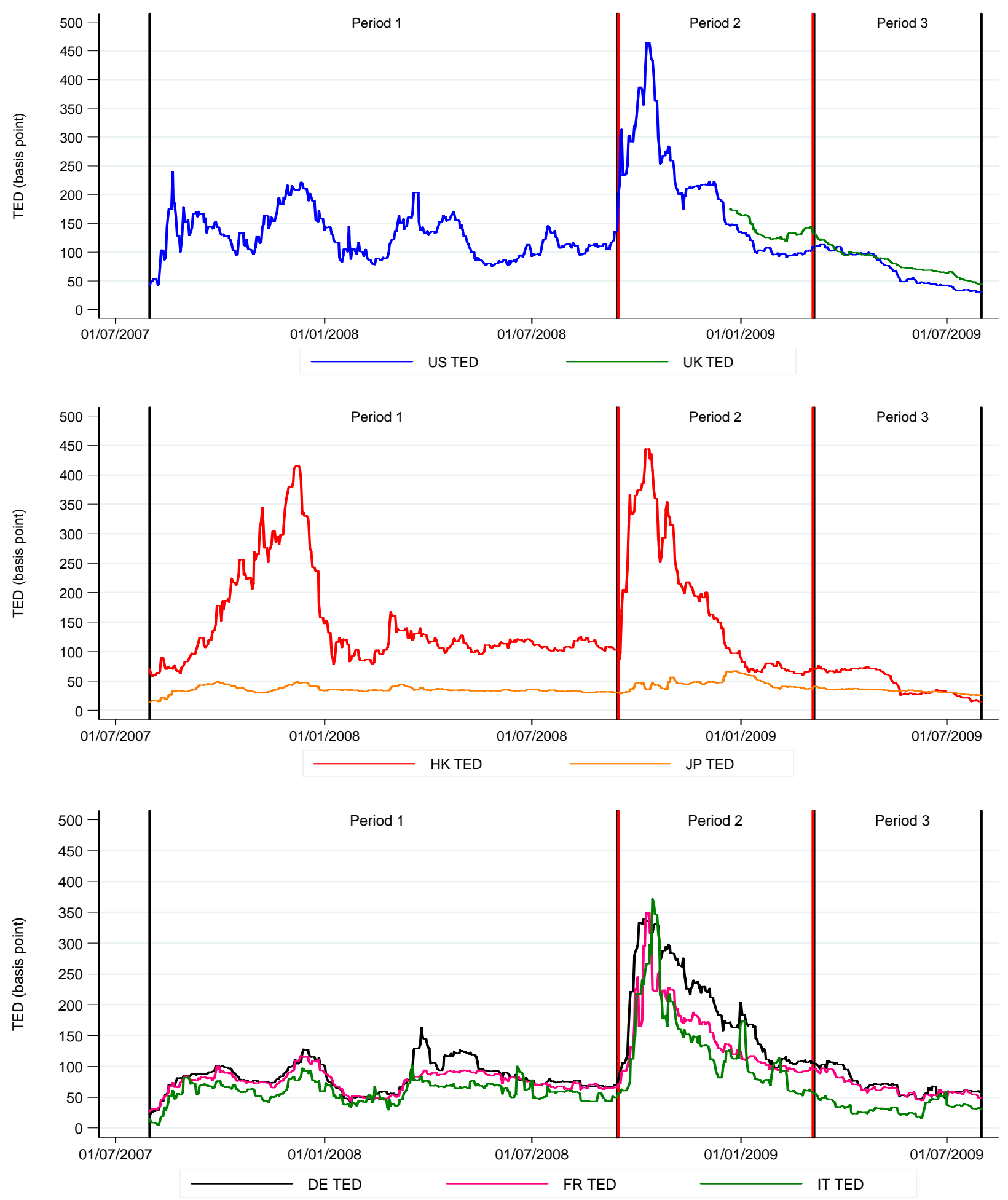

Figure 1: TED (or equivalent spread) by countries. Source: Bloomberg.

NOTES: TED for USA (US); TED equivalent spreads for United Kingdom (UK), Honk-Kong (HK), Japan (JP), DE (Germany), France (FR) and Italy (IT). There is not TED equivalent spreads for other countries. United Kingdom has 3months government bonds since 22 December 2008. See text for periods. 


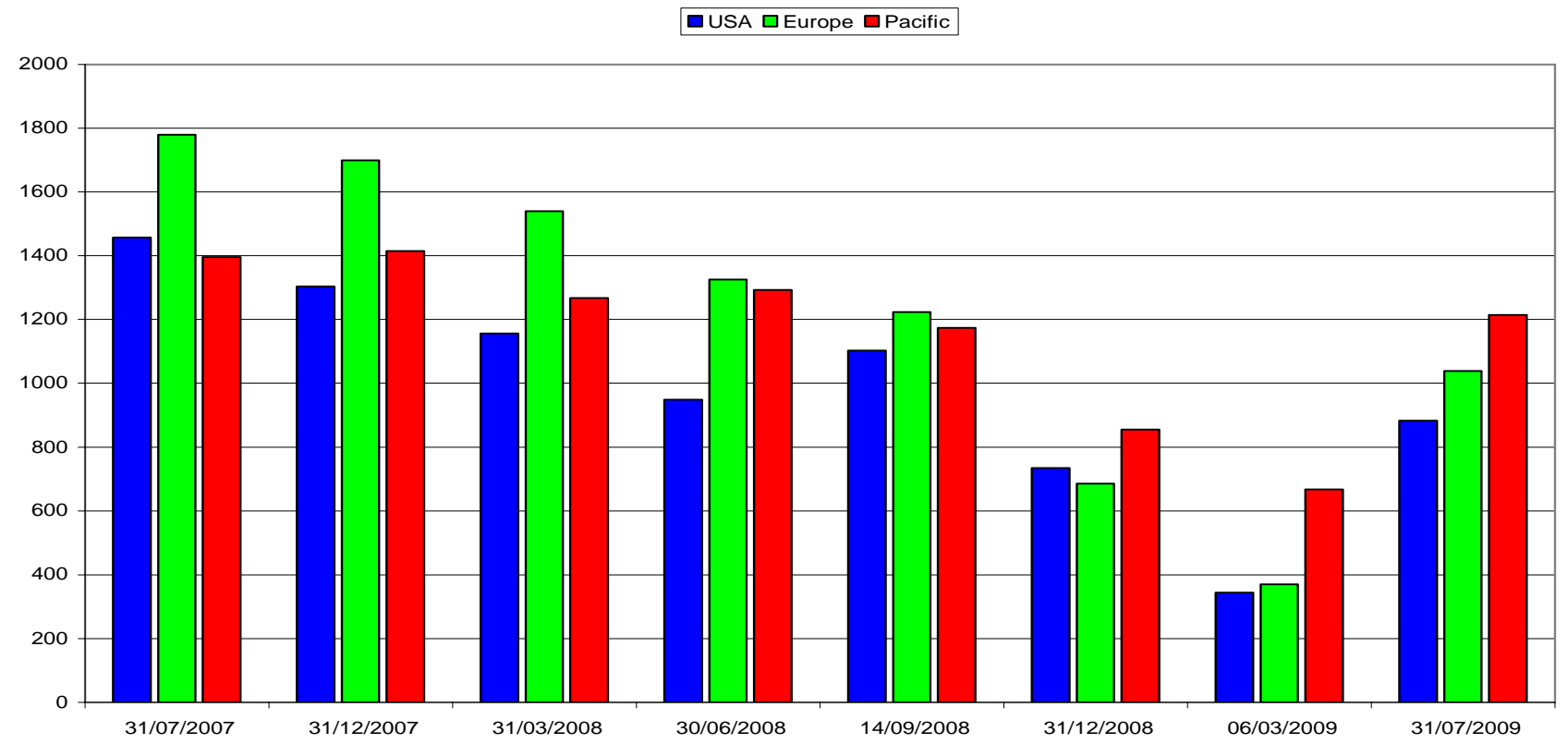

Figure 2: Market capitalization of a sample of US, European , and Pacific region banks from end of July, 2007 to July 31, 2009, in US\$ billion.

NOTES: CME Group Inc., Discover Financial Services, Fukuoka Financial Group, and Invesco Ltd were excluded from the sample of 120 banks because they did not make the list at the end of July 2007. Source: Bloomberg (August 7, 2009).

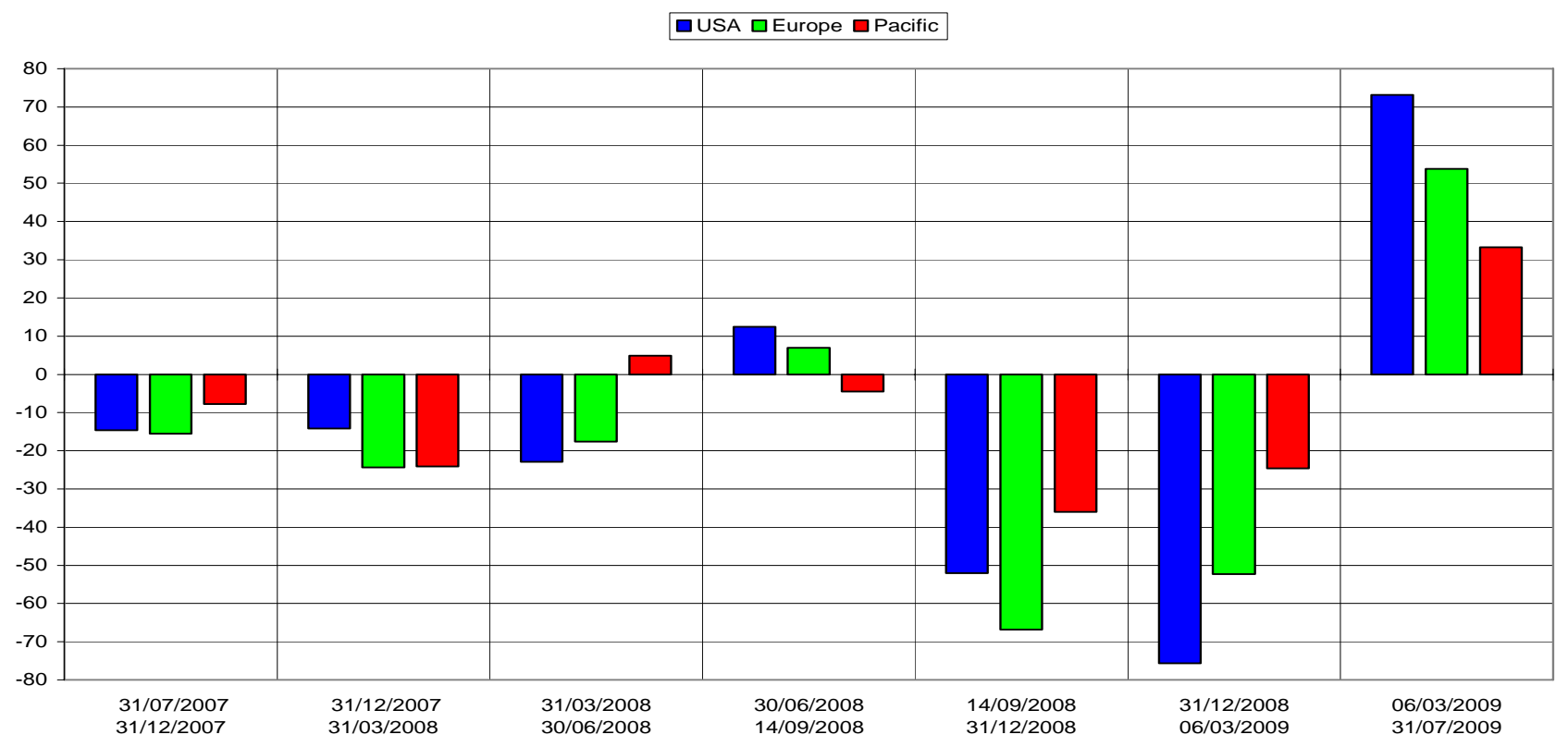

Figure 3: Holding-period dollar rates of return on a sample of US, European, and Pacific region banks from end of July, 2007 to July 31, 2009.

NOTES: CME Group Inc., Discover Financial Services, Fukuoka Financial Group, and Invesco Ltd were excluded from the sample of 120 banks because they did not make the list at the end of July 2007. Source: Bloomberg (August 7, 2009). 


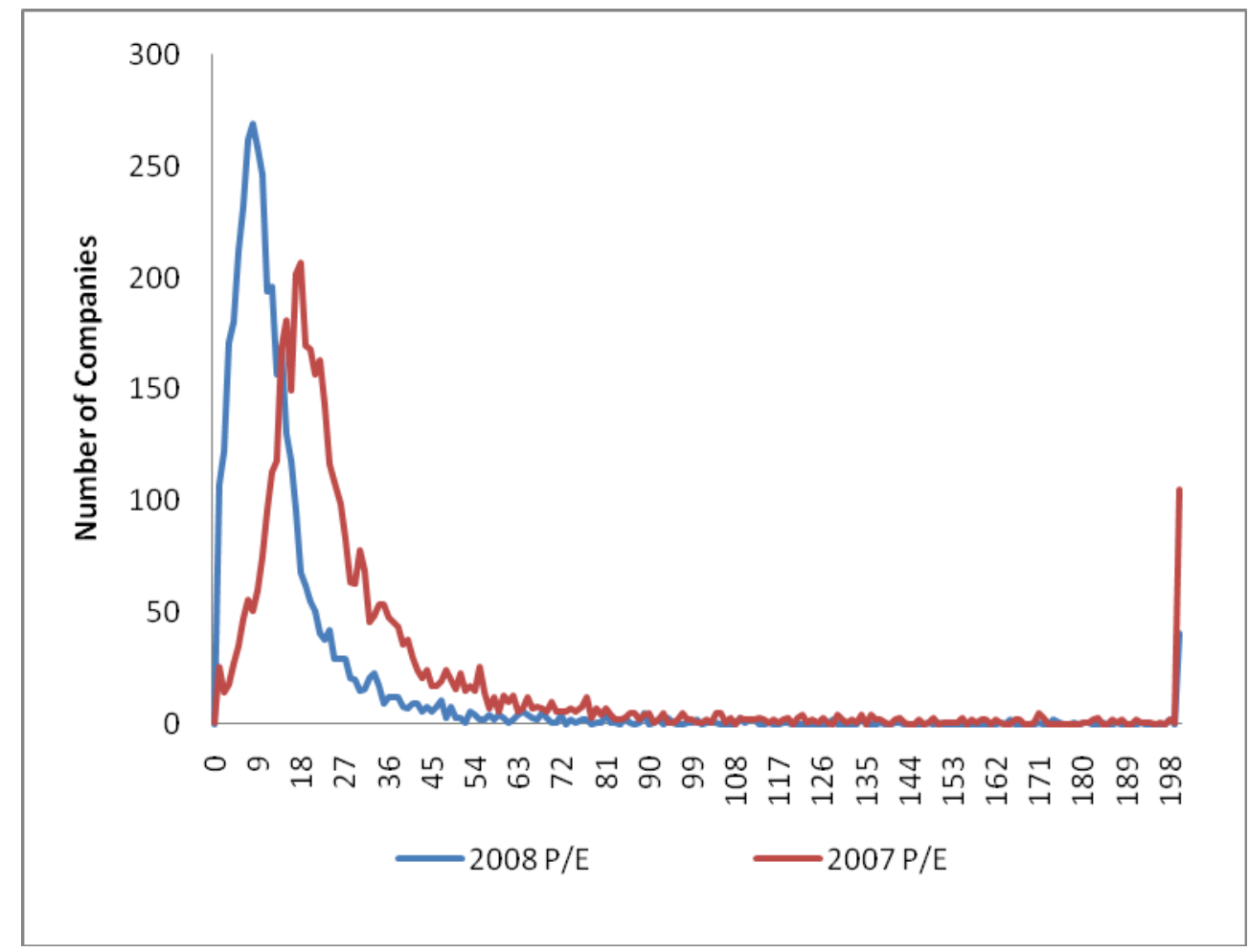

Figure 4: Shift in the price-earnings ratio of US stocks, 2007-2008.

NOTES: 2007 P/E and 2008 P/E observations refer to end of January 2008 and 2009, respectively. Source: F529 class notes by Professor Charles Trzcinka, Indiana University, Department of Finance. 
Cumulative Value of General Announcements in Banking System (in billion USD) from 1 to 15 October 2008

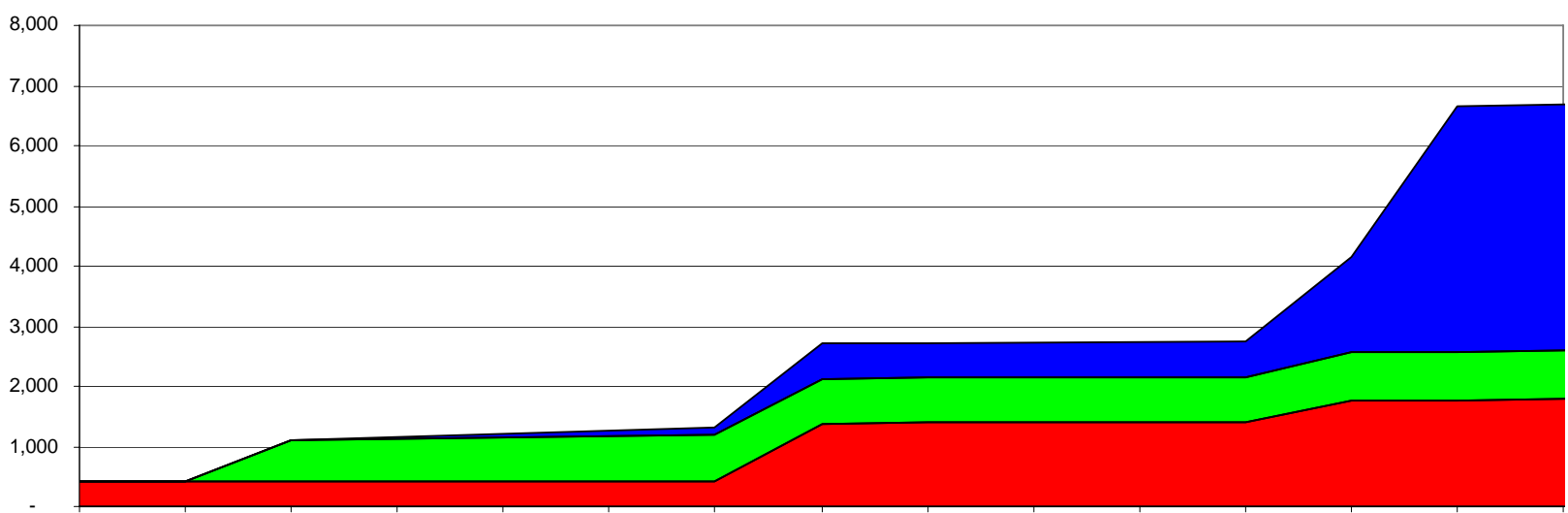

01/10/2008 02/10/2008 03/10/2008 04/10/2008 05/10/2008 06/10/2008 07/10/2008 08/10/2008 09/10/2008 10/10/2008 11/10/2008 12/10/2008 13/10/2008 14/10/2008 15/10/2008 $\square$ Capital Injection $\square$ Asset Purchase and Guarantees $\square$ Debt Guarantees

Figure 5: Cumulative value of general announcements. October 1 through 15 2008. USD billions 
Table 1: Rates of returns local currency and in dollars on selected US, European and Pacific region banks, in percent, end of July 2007 to July 31, 2009.

\begin{tabular}{|c|c|c|c|c|c|c|c|c|c|c|}
\hline \multirow[t]{2}{*}{ Area } & \multirow[t]{2}{*}{ Country } & \multicolumn{3}{|c|}{$31 / 07 / 2007$ 14/09/2008 } & \multicolumn{3}{|c|}{$31 / 07 / 200706 / 03 / 2009$} & \multicolumn{3}{|c|}{$31 / 07 / 200731 / 07 / 2009$} \\
\hline & & LCU & $\mathrm{EXC}$ & USD & LCU & $\mathrm{EXC}$ & USD & LCU & $\mathrm{EXC}$ & USD \\
\hline \multirow[t]{14}{*}{ Europe } & AT & -42.29 & 3.31 & -40.38 & -199.61 & -7.86 & -191.78 & -104.68 & 4.06 & -104.87 \\
\hline & $\mathrm{BE}$ & -54.67 & 3.31 & -53.17 & -287.72 & -7.86 & -272.96 & -160.25 & 4.06 & -162.69 \\
\hline & $\mathrm{DE}$ & -62.64 & 3.31 & -61.40 & -297.29 & -7.86 & -281.78 & -207.92 & 4.06 & -212.30 \\
\hline & ES & -43.14 & 3.31 & -41.26 & -101.61 & -7.86 & -101.48 & -45.16 & 4.06 & -42.93 \\
\hline & FR & -64.80 & 3.31 & -63.64 & -178.66 & -7.86 & -172.47 & -104.34 & 4.06 & -104.52 \\
\hline & GR & -42.61 & 3.31 & -40.71 & -161.66 & -7.86 & -156.81 & -85.64 & 4.06 & -85.06 \\
\hline & IE & -88.06 & 3.31 & -87.66 & -403.63 & -7.86 & -379.75 & -239.22 & 4.06 & -244.87 \\
\hline & IT & -42.65 & 3.31 & -40.75 & -134.29 & -7.86 & -131.59 & -79.21 & 4.06 & -78.37 \\
\hline & PT & -92.74 & 3.31 & -92.50 & -153.90 & -7.86 & -149.66 & -121.45 & 4.06 & -122.32 \\
\hline & $\mathrm{CH}$ & 13.52 & 5.88 & 20.19 & 14.64 & 4.21 & 19.47 & 15.44 & 11.94 & 29.22 \\
\hline & DK & -49.98 & 3.10 & -48.43 & -169.91 & -8.01 & -164.30 & -77.06 & 3.97 & -76.15 \\
\hline & NO & -30.46 & 1.44 & -29.45 & -126.41 & -19.53 & -121.25 & -37.62 & -5.14 & -40.82 \\
\hline & SE & -45.72 & -0.02 & -45.73 & -155.59 & -31.50 & -138.08 & -72.10 & -7.22 & -74.11 \\
\hline & UK & -54.12 & -12.92 & -60.05 & -233.67 & -36.69 & -184.63 & -116.96 & -19.76 & -113.61 \\
\hline \multicolumn{2}{|c|}{ Europe Total } & -50.92 & 1.05 & -50.32 & -175.20 & -13.32 & -163.14 & -96.96 & 0.19 & -96.53 \\
\hline \multirow[t]{3}{*}{ Pacific } & HK & -12.04 & 0.39 & -11.70 & -77.53 & 0.92 & -77.33 & -12.71 & 0.98 & -11.86 \\
\hline & JP & -43.66 & 10.26 & -37.87 & -109.63 & 19.65 & -111.53 & -78.37 & 23.12 & -73.36 \\
\hline & $\mathrm{AU}$ & -30.34 & -5.06 & -33.87 & -81.02 & -29.35 & -86.59 & -40.53 & -3.01 & -42.32 \\
\hline \multicolumn{2}{|c|}{ Pacific Total } & -30.34 & 3.42 & -28.54 & -92.49 & 1.89 & -94.60 & -48.28 & 9.76 & -46.23 \\
\hline USA & US & -39.27 & 0.00 & -39.27 & -166.92 & 0.00 & -166.92 & -93.74 & 0.00 & -93.74 \\
\hline \multicolumn{2}{|l|}{ USA Total } & -39.27 & 0.00 & -39.27 & -166.92 & 0.00 & -166.92 & -93.74 & 0.00 & -93.74 \\
\hline
\end{tabular}

NOTES: $L C U$ = rate of return in local-currency units; EXC = depreciation/appreciation of the US dollar relative to the local currency; USD = rate of return in dollars; $\mathrm{AT}=\mathrm{Austria}$; $\mathrm{BE}=\mathrm{Belgium}$; $\mathrm{CH}=$ Switzerland; $\mathrm{DE}=\mathrm{Germany}$; $\mathrm{DK}=$ Denmark; $\mathrm{ES}=\mathrm{Spain} ; \mathrm{FR}=$ France; $\mathrm{GR}=\mathrm{Greece} ; \mathrm{IE}=$ Eire; IT=Italy; $\mathrm{NO}=$ Norway; $\mathrm{PT}=\mathrm{Portugal} ; \mathrm{SE}=\mathrm{Sweden}$; $\mathrm{UK}=$ United Kingdom; AU=Australia; HK=Hong-Kong; JP=Japan; US=United States. CME Group Inc., Discover Financial Services, Fukuoka Financial Group, and Invesco Ltd were excluded from the sample of 120 banks because they did not make the list at the end of July 2007. Source: Bloomberg (August 7, 2009). 
Table 2: Government interventions to support banks, by country and types through February 2009 (in million USD)

\begin{tabular}{|l|rrrrr|r|}
\hline \multirow{3}{*}{ Country } & \multicolumn{3}{|c|}{ Public intervention in banks by country and typology } & \multirow{2}{*}{ Total } \\
\cline { 2 - 5 } & Bad Banks & $\begin{array}{c}\text { Convertible } \\
\text { Bonds }\end{array}$ & $\begin{array}{c}\text { Debt } \\
\text { Guaranty }\end{array}$ & $\begin{array}{c}\text { Equity } \\
\text { Funding }\end{array}$ & Nationalization & \multicolumn{1}{c|}{} \\
\hline AT & & & & & $0,00^{(a)}$ & 0,000 \\
BE & & & & 10,504 & 6,759 & 17,263 \\
CH & & 6,799 & & & & 6,799 \\
DE & & 10,430 & 144,856 & 16,101 & & 171,387 \\
EI & & & 1,923 & 5,550 & 0,000 & 7,473 \\
FR & & & & 18,204 & & 18,204 \\
IS & & & & & 0,829 & 0,829 \\
LU & & 4,050 & & & & 4,050 \\
NL & 42,543 & & & 63,037 & $0,00^{(a)}$ & 65,753 \\
UK & & & & 278,804 & 63,037 \\
US & & & & & & 278,804 \\
\hline \multicolumn{1}{c|}{ Total } & 42,543 & 21,278 & 146,779 & 392,200 & 30,799 & 633,599 \\
\hline
\end{tabular}

NOTES: $\mathrm{AT}=$ Austria; $\mathrm{BE}=$ Belgium; $\mathrm{CH}=$ Switzerland; $\mathrm{DE}=$ Germany; $\mathrm{DK}=$ Denmark; $\mathrm{ES}=$ Spain; $\mathrm{FR}=$ France; $\mathrm{GR}=\mathrm{Greece}$; IE=Eire; IT=Italy; $\mathrm{NO}=$ Norway; $\mathrm{PT}=$ Portugal; $\mathrm{SE}=$ Sweden; UK=United Kingdom; $\mathrm{AU}=$ Australia; HK=Hong-Kong; JP=Japan; US=United States. (a) Government bought distressed banks for 2 euro in Austria and for free in UK. Source: Mediobanca (10 February 2009). 
Table 3: Overview of commitments and outlays as of 10 June 2009*

\begin{tabular}{|c|c|c|c|c|c|c|c|c|c|c|c|c|c|c|c|c|}
\hline & & \multicolumn{3}{|c|}{ Capital Injections } & \multicolumn{3}{|c|}{ Debt Guarantees } & \multicolumn{3}{|c|}{ Asset purchase } & \multicolumn{3}{|c|}{ Asset Guarantees (1) } & \multicolumn{3}{|c|}{ Total } \\
\hline \multicolumn{2}{|c|}{$\begin{array}{l}\text { Euro billions and } \\
\text { percentage points }\end{array}$} & & $\begin{array}{c}\% \text { of } \\
\text { GDP } \\
(2008)\end{array}$ & $\begin{array}{c}\% \text { of } \\
\text { banking } \\
\text { sector } \\
\text { assets } \\
\text { (end-2008) }\end{array}$ & & $\begin{array}{c}\% \text { of } \\
\text { GDP } \\
(2008)\end{array}$ & $\begin{array}{c}\% \text { of } \\
\text { banking } \\
\text { sector } \\
\text { assets } \\
\text { (end-2008) }\end{array}$ & & $\begin{array}{c}\% \text { of } \\
\text { GDP } \\
(2008)\end{array}$ & $\begin{array}{c}\% \text { of } \\
\text { banking } \\
\text { sector } \\
\text { assets } \\
\text { (end-2008) }\end{array}$ & & $\begin{array}{c}\% \text { of } \\
\text { GDP } \\
(2008)\end{array}$ & $\begin{array}{c}\% \text { of } \\
\text { banking } \\
\text { sector } \\
\text { assets } \\
\text { (end-2008) }\end{array}$ & $\begin{array}{c}\text { Euro } \\
\text { billions }\end{array}$ & $\begin{array}{c}\% \text { of } \\
\text { GDP } \\
(2008)\end{array}$ & $\begin{array}{c}\% \text { of } \\
\text { banking } \\
\text { sector } \\
\text { assets } \\
\text { (end-2008) }\end{array}$ \\
\hline \multirow[t]{2}{*}{ Australia } & Commitments & - & - & - & UNS & UNS & UNS & - & - & - & - & - & - & UNS & UNS & UNS \\
\hline & Outlays & - & - & - & 62 & 10.4 & 4.6 & - & - & - & - & - & - & 62 & 10.4 & 4.6 \\
\hline \multirow[t]{2}{*}{ Canada } & Commitments & - & - & - & UNS & UNS & UNS & - & - & - & - & - & - & UNS & UNS & UNS \\
\hline & Outlays & - & - & - & $\mathbf{0}$ & 0 & 0 & - & - & - & - & - & - & - & - & - \\
\hline \multirow[t]{2}{*}{ France } & Commitments & 43 & 2.2 & 0.6 & 320 & 16.4 & 4.2 & - & - & - & 5 & 0.2 & 0.1 & 368 & 18.9 & 4.8 \\
\hline & Outlays & 28 & 1.4 & 0.4 & 72 & 3.7 & 0.9 & - & - & - & 5 & 0.2 & 0.1 & 104 & 5.3 & 1.4 \\
\hline \multirow[t]{2}{*}{ Germany } & Commitments & 80 & 3.2 & 1 & 420 & 16.9 & 5.3 & UNS & UNS & UNS & 200 & 8 & 2.5 & 700 & 28.1 & 8.9 \\
\hline & Outlays & 22 & 0.9 & 0.3 & 129 & 5.2 & 1.6 & $\mathbf{0}$ & 0 & 0 & $\mathbf{0}$ & 0 & 0 & 151 & 6.1 & 1.9 \\
\hline \multirow[t]{2}{*}{ Italy } & Commitments & 20 & 1.3 & 0.5 & UNS & UNS & UNS & - & - & - & - & - & - & UNS & UNS & UNS \\
\hline & Outlays & 10 & 0.6 & 0.3 & $\mathbf{0}$ & 0 & 0 & - & - & - & - & - & - & 10 & 0.6 & 0.3 \\
\hline \multirow[t]{2}{*}{ Japan } & Commitments & 105 & 2.5 & 0.9 & - & - & - & 8 & 0.2 & 0.1 & - & - & - & 113 & 2.7 & 0.9 \\
\hline & Outlays & 3 & 0.1 & 0 & - & - & - & $\mathbf{0}$ & 0 & 0 & - & - & - & 3 & 0.1 & 0 \\
\hline \multirow{2}{*}{ Netherlands } & Commitments & 37 & 6.2 & 1.7 & 200 & 33.6 & 9.0 & - & - & - & 28 & 4.7 & 1.3 & 265 & 44.6 & 11.9 \\
\hline & Outlays & 31 & 5.1 & 1.4 & 40 & 6.8 & 1.8 & - & - & - & 28 & 4.7 & 1.3 & 99 & 16.6 & 4.4 \\
\hline \multirow[t]{2}{*}{ Spain } & Commitments & UNS & UNS & UNS & 100 & 9.1 & 3 & - & - & - & - & - & - & UNS & UNS & UNS \\
\hline & Outlays & $\mathbf{0}$ & 0 & 0 & 31 & 2.8 & 0.9 & - & - & - & - & - & - & 31 & 2.8 & 0.9 \\
\hline \multirow[t]{2}{*}{ Switzerland } & Commitments & 4 & 1.1 & 0.2 & UNS & UNS & UNS & 27 & 7.6 & 1.3 & - & - & - & UNS & UNS & UNS \\
\hline & Outlays & 4 & 1.1 & 0.2 & $\mathbf{0}$ & 0 & 0 & 27 & 7.6 & 1.3 & - & - & - & 31 & 8.7 & 1.5 \\
\hline \multirow[t]{2}{*}{$\begin{array}{l}\text { United } \\
\text { Kingdom }\end{array}$} & Commitments & 54 & 3.4 & 0.7 & 269 & 17.2 & 3.4 & - & - & - & 523 & 33.4 & 6.7 & 845 & 54 & 10.8 \\
\hline & Outlays & 54 & 3.4 & 0.7 & 113 & 7.2 & 1.4 & - & - & - & 523 & 33.4 & 6.7 & 690 & 44.1 & 8.8 \\
\hline \multirow{2}{*}{ United States } & Commitments & 335 & 3 & 3.4 & 1,760 & 15.7 & 18 & 115 & 1 & 1.2 & 281 & 2.5 & 2.9 & 2,491 & 22.3 & 25.5 \\
\hline & Outlays & 237 & 2.1 & 2.4 & 271 & 2.4 & 2.8 & 36 & 0.3 & 0.4 & 281 & 2.5 & 2.9 & 825 & 7.4 & 8.4 \\
\hline \multicolumn{2}{|c|}{ Total commitments } & 677 & 2.6 & 1.1 & 3,131 & 11.8 & 5.2 & 150 & 0.6 & 0.3 & 1,036 & 3.9 & 1.7 & 4,994 & 18.8 & 8.3 \\
\hline \multicolumn{2}{|c|}{ Total outlays } & 387 & 1.5 & 0.6 & 719 & 2.7 & 1.2 & 64 & 0.2 & 0.1 & 836 & 3.2 & 1.4 & 2,006 & 7.6 & 3.3 \\
\hline
\end{tabular}

* As of 10 June 2009 unless otherwise specified. UNS = unspecified amount; "-_" = no program/action. Banking sector assets are consolidated data of: for Australia, banks, credit unions, building societies and corporations; for Canada, chartered banks; for Japan, depository corporations (banks and collectively managed trusts); for Switzerland, all domestic banks; for the five euro area countries and the United Kingdom, monetary financial institutions; and for the United States, commercial banks.

Source: Panetta et al. (2009, Table 1.2). 
Table 4: Overview of Policy Measures from 15 September 2008 to 1 June 2009.

\begin{tabular}{|c|c|c|c|c|c|c|c|}
\hline \multicolumn{7}{|c|}{ Amounts Pledged (bn)* } & \multirow[t]{2}{*}{ Note } \\
\hline Country & $\begin{array}{l}\text { Capital } \\
\text { Injections }\end{array}$ & $\begin{array}{c}\text { New Debt Issuance } \\
\text { Guarantees }\end{array}$ & Others & $\begin{array}{c}\text { Local } \\
\text { Currency (bn) }\end{array}$ & EURbn & $\begin{array}{l}\% \text { of } \\
\text { GDP }\end{array}$ & \\
\hline Austria & 15 & 85 & & 100 & 100 & 37.0 & Includes Dexia, Ethias, Fortis and KBC \\
\hline Belgium & 19.6 & & & 19.6 & 19.6 & 5.9 & \\
\hline Cyprus & 2 & & & 2 & 2 & 12.8 & \\
\hline Finland & 4 & 50 & & 54 & 54 & 30.1 & \\
\hline France & 24 & 320 & & 344 & 344 & 18.2 & Includes Dexia \\
\hline Germany & 80 & 400 & & 480 & 480 & 19.8 & \\
\hline Greece & 5 & 15 & 8 & 28 & 28 & 12.3 & \\
\hline Ireland & 7 & 400 & & 407 & 407 & 213.5 & \\
\hline Italy & 12 & & 40 & 52 & 52 & 3.4 & \\
\hline Luxembourg & 2.9 & & & 2.9 & 2.9 & 0.8 & Includes Fortis, but not ING \\
\hline Netherlands & 36.8 & 200 & & 236.8 & 236.8 & 41.6 & Illiquid Assets Facility \\
\hline Portugal & 4 & 20 & & 24 & 24 & 14.7 & \\
\hline Slovenia & & 12 & 1 & 13 & 13 & 39.0 & \\
\hline Spain & & 209 & 50 & 259 & 259 & 24.6 & Includes guarantee on loan to Caja Castilla La Mancha \\
\hline Eurozone & 197.8 & 1,711 & 99 & 2,028 & 1,955 & 21.0 & \\
\hline Australia & & & 8 & 8 & 4 & 0.7 & \\
\hline Canada & & 218 & 125 & 343 & 259 & 22.3 & \\
\hline Denmark & 100 & & & 100 & 13.4 & 5.9 & Plus losses over DKK35bn on bank liabilities \\
\hline Hungary & $1.5 * *$ & $1.5^{* *}$ & & $3.1 * *$ & 2.3 & 2.2 & \\
\hline Japan & 13000 & & 7691 & 20691 & 161.2 & 4.0 & \\
\hline Norway & 100 & & 350 & 450 & 51.1 & 19.8 & \\
\hline Qatar & $6^{* *}$ & & & $6^{* *}$ & 4.7 & 8.8 & \\
\hline SaudiArabia & $3 * *$ & & & $3^{* *}$ & 2.4 & 0.8 & \\
\hline SouthKorea & $14.2^{* *}$ & $100 * *$ & $40.8^{* *}$ & $155^{*}$ & 114.9 & 16.3 & \\
\hline Sweden & 65 & 1,500 & & 1,565 & 145.8 & 51.0 & \\
\hline Switzerland & 6 & & & 6 & 4 & 1.0 & Capitalisation of UBS Excludes Special Liquidity \\
\hline UK & 678.1 & 250 & 635 & 963.1 & 1,059 & 68.7 & Scheme (GBP200bn) but includes Asset Protection Scheme \\
\hline UAE & $19 * *$ & & & $19 * *$ & 14.7 & 9.6 & \\
\hline US & 350 & $1,400 * * *$ & $750 * * * *$ & 2,500 & 1,925 & 18.1 & Does not include Fed's facilities, such as the MMIFF but does include TALF \\
\hline
\end{tabular}

NOTES: * Includes capital injections, asset buying and guarantees on debt issuance. Excludes deposit guarantees. ** In USD *** FDIC estimate of total size of unsecured debt falling under its guarantee. **** Includes USD500bn for PPIF, USD200bn for TALF, USD50bn for foreclosure prevention. Source: BNP Paribus. 
Table 5: Timeline of general announcements (USD millions)

\begin{tabular}{|c|c|c|c|c|c|c|}
\hline \multirow[b]{2}{*}{ Date } & \multirow[b]{2}{*}{ Country } & \multicolumn{4}{|c|}{ Measure } & \multirow[b]{2}{*}{ Total } \\
\hline & & $\begin{array}{c}\text { Capital } \\
\text { Injection }\end{array}$ & $\begin{array}{c}\text { Debt } \\
\text { Guarantees }\end{array}$ & $\begin{array}{l}\text { Asset Purchase } \\
\text { and Guarantees }\end{array}$ & Nationalization & \\
\hline $21 / 04 / 08$ & UK & 99,065 & & & & 99,065 \\
\hline $30 / 09 / 08$ & EI & 14,081 & & & & 14,081 \\
\hline $02 / 10 / 08$ & GR & 6,927 & & & & 6,927 \\
\hline $03 / 10 / 08$ & US & & & 700,000 & & 700,000 \\
\hline $05 / 10 / 08$ & DK & 0.1 & & & & 0.1 \\
\hline $07 / 10 / 08$ & $\mathrm{ES}$ & & 136,490 & 68,245 & & 204,735 \\
\hline 08/10/08 & $\begin{array}{l}\text { IT } \\
\text { UK }\end{array}$ & $\begin{array}{c}- \\
952,050\end{array}$ & 432,750 & & & $\begin{array}{c}- \\
1,384,800\end{array}$ \\
\hline $12 / 10 / 08$ & $\begin{array}{l}\text { AU } \\
\text { PT }\end{array}$ & & $\begin{array}{c}- \\
26,942 \\
\end{array}$ & & & $\begin{array}{c}- \\
26,942 \\
\end{array}$ \\
\hline $13 / 10 / 08$ & $\begin{array}{l}\text { DE } \\
\text { FR } \\
\text { IT } \\
\text { US }\end{array}$ & $\begin{array}{r}53,884 \\
53,884 \\
250,000 \\
\end{array}$ & $\begin{array}{c}545,669 \\
431,072 \\
-\end{array}$ & 53,884 & & $\begin{array}{c}653,437 \\
484,956 \\
- \\
250,000\end{array}$ \\
\hline $14 / 10 / 08$ & $\begin{array}{l}\mathrm{HK} \\
\mathrm{US}\end{array}$ & - & $2,250,000$ & & & $\begin{array}{c}- \\
2,250,000\end{array}$ \\
\hline $16 / 10 / 08$ & $\mathrm{CH}$ & 60,000 & & & & 60,000 \\
\hline $17 / 10 / 08$ & $\mathrm{BE}$ & & - & & & - \\
\hline $24 / 10 / 08$ & $\mathrm{NO}$ & & 51,071 & & & 51,071 \\
\hline $26 / 10 / 08$ & $\mathrm{AT}$ & 18,959 & 107,432 & & & 126,390 \\
\hline $29 / 10 / 08$ & SE & 195,277 & & & & 195,277 \\
\hline $03 / 11 / 08$ & $\mathrm{AT}$ & & 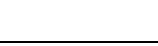 & & 0 & 0 \\
\hline $05 / 11 / 08$ & $\mathrm{CH}$ & & - & & & - \\
\hline $28 / 11 / 08$ & IT & - & & & & - \\
\hline $17 / 12 / 08$ & JP & 136,612 & & & & 136,612 \\
\hline $18 / 01 / 09$ & $\mathrm{DK}$ & 17,770 & & & & 17,770 \\
\hline 19/01/09 & UK & & & 73,685 & & 73,685 \\
\hline $03 / 02 / 09$ & $\mathrm{JP}$ & & & 11,225 & & 11,225 \\
\hline $10 / 02 / 09$ & US & - & & - & & - \\
\hline $12 / 02 / 09$ & EI & 8,975 & & & & 8,975 \\
\hline $25 / 02 / 09$ & IT & 15,277 & & & & 15,277 \\
\hline $26 / 02 / 09$ & UK & & & 466,115 & & 466,115 \\
\hline 06/03/09 & $\mathrm{DE}$ & & & & - & - \\
\hline $17 / 03 / 09$ & JP & 10,116 & & & & 10,116 \\
\hline $23 / 03 / 09$ & US & 500,000 & & & & 500,000 \\
\hline $13 / 05 / 09$ & $\mathrm{DE}$ & & & 272,240 & & 272,240 \\
\hline 09/06/09 & US & - & & & & - \\
\hline $22 / 07 / 09$ & $\mathrm{HK}$ & & - & & & - \\
\hline \multicolumn{2}{|c|}{ Total } & $2,392,877$ & $3,981,426$ & $1,645,394$ & - & $8,019,696$ \\
\hline
\end{tabular}

NOTES: - = unspecified amount. Sources: Mediobanca, BIS-BdI, DLA Piper, International Capital Market Association, and websites of national Ministries of Treasury or Finance. 
Table 6: Timeline of specific announcements (USD millions)

\begin{tabular}{|c|c|c|c|c|c|}
\hline \multirow{2}{*}{ Data } & \multirow{2}{*}{ Country } & \multirow{2}{*}{ Bank } & \multicolumn{3}{|c|}{ Measure } \\
\hline & & & AP & $\mathrm{CI}$ & DG \\
\hline $14 / 03 / 2008$ & US & JP Morgan Chase \& Co. & & & 29000 \\
\hline $30 / 09 / 2008$ & $\begin{array}{l}\mathrm{BE} \\
\mathrm{FR}\end{array}$ & $\begin{array}{l}\text { Dexia } \\
\text { Dexia }\end{array}$ & & $\begin{array}{l}4224.3 \\
4224.3\end{array}$ & \\
\hline $06 / 10 / 2008$ & $\mathrm{DE}$ & Hypo Real Estate & & & 67540 \\
\hline $13 / 10 / 2008$ & UK & $\begin{array}{l}\text { Lloyds TSB } \\
\text { RBS }\end{array}$ & & $\begin{array}{r}22900.7 \\
26942\end{array}$ & \\
\hline $27 / 10 / 2008$ & $\mathrm{BE}$ & $\mathrm{KBC}$ & & 4356.1 & \\
\hline $28 / 10 / 2008$ & US & $\begin{array}{l}\text { Bank of America } \\
\text { Bank of New York Mellon } \\
\text { Citigroup } \\
\text { Goldman Sachs Group } \\
\text { JP Morgan Chase \& Co. } \\
\text { Morgan Stanley } \\
\text { State Street Corp. } \\
\text { Wells Fargo Bank }\end{array}$ & & $\begin{array}{r}15000 \\
3000 \\
25000 \\
10000 \\
25000 \\
10000 \\
2000 \\
25000\end{array}$ & \\
\hline $03 / 11 / 2008$ & $\mathrm{DE}$ & Commerzbank & & 10429.58 & \\
\hline $13 / 11 / 2008$ & $\mathrm{DE}$ & Hypo Real Estate & & & 25052 \\
\hline $17 / 11 / 2008$ & US & $\begin{array}{l}\text { BB\&T Corp. } \\
\text { Comerica } \\
\text { First Horizon National Corp. } \\
\text { Huntington Bancshares } \\
\text { Key Corp. } \\
\text { Marshall \& Ilsley Corp. } \\
\text { Northern Trust Corp } \\
\text { Regions Financial Corp } \\
\text { Sun Trust Banks } \\
\text { US Bancorp } \\
\text { Zions Bancorporation }\end{array}$ & & $\begin{array}{r}3133.64 \\
2250 \\
866.54 \\
1398.071 \\
2500 \\
1715 \\
1576 \\
3500 \\
3500 \\
6599 \\
1400\end{array}$ & \\
\hline $21 / 11 / 2008$ & $\mathrm{DE}$ & Hypo Real Estate & & & 25062 \\
\hline $23 / 11 / 2008$ & US & Citigroup & 262000 & & \\
\hline $09 / 12 / 2008$ & $\mathrm{DE}$ & Hypo Real Estate & & & 12937 \\
\hline $11 / 12 / 2008$ & FR & $\begin{array}{l}\text { BNP Paribas } \\
\text { Crédit Agricole } \\
\text { Societé Générale }\end{array}$ & & $\begin{array}{r}3389.97 \\
3988.2 \\
2259.98\end{array}$ & \\
\hline $21 / 12 / 2008$ & EI & $\begin{array}{l}\text { Allied Irish Banks } \\
\text { Bank of Ireland Group }\end{array}$ & & $\begin{array}{l}2775 \\
2775\end{array}$ & \\
\hline $23 / 12 / 2008$ & US & M\&T BankCorp & & 600 & \\
\hline $31 / 12 / 2008$ & US & $\begin{array}{l}\text { CIT Group } \\
\text { Citigroup } \\
\text { Fifth Third Bancorp } \\
\text { PNC Financial Services Group } \\
\text { Sun Trust Banks }\end{array}$ & & $\begin{array}{r}2330 \\
20000 \\
3408 \\
7579.2 \\
1350\end{array}$ & \\
\hline $09 / 01 / 2009$ & US & $\begin{array}{l}\text { American Express Company } \\
\text { Bank of America }\end{array}$ & & $\begin{array}{r}3388.89 \\
10000\end{array}$ & \\
\hline $14 / 01 / 2009$ & AT & Erste Group Bank & & & 7904.4 \\
\hline $16 / 01 / 2009$ & US & $\begin{array}{l}\text { Bank of America } \\
\text { Citigroup }\end{array}$ & 97000 & 301000 & \\
\hline $20 / 01 / 2009$ & $\mathrm{DE}$ & Hypo Real Estate & & & 15535.2 \\
\hline $11 / 02 / 2009$ & $\mathrm{DE}$ & Hypo Real Estate & & & 12893 \\
\hline $12 / 02 / 2009$ & EI & $\begin{array}{l}\text { Allied IrishBanks } \\
\text { Bank of Ireland Group }\end{array}$ & & $\begin{array}{l}1923.3 \\
1923.3 \\
\end{array}$ & \\
\hline $26 / 02 / 2009$ & UK & Royal Bank of Scotland & & 16593.2 & \\
\hline
\end{tabular}




\begin{tabular}{|c|c|l|c|}
\hline $27 / 02 / 2009$ & AT & Erste Group Bank & 3418.74 \\
\hline $07 / 03 / 2009$ & UK & LloydsTSB & 329524 \\
\hline $10 / 03 / 2009$ & IT & Banco Popolare & 1849.04 \\
\hline $13 / 03 / 2009$ & US & Discover Financial Services & 1224.558 \\
\hline $18 / 03 / 2009$ & IT & Unicredit Group & 2622 \\
\hline $20 / 03 / 2009$ & IT & Intesa Sanpaolo & 5426.4 \\
\hline $24 / 03 / 2009$ & IT & Banca Popolare di Milano & 676.2 \\
\hline $27 / 03 / 2009$ & IT & Banca Monte dei Paschi di Siena & \\
\hline $31 / 03 / 2009$ & FR & BNP Paribas & 2528.14 \\
\hline $13 / 04 / 2009$ & US & Wells Fargo Bank & 79763.11 \\
\hline $17 / 04 / 2009$ & US & Bank of America & 362671.9 \\
\hline Total & & & \\
\hline
\end{tabular}

NOTES: $\mathrm{AP}=$ Asset Guarantees and Purchase; $\mathrm{CI}=$ Capital Injection; $\mathrm{DG}=$ Debt Guarantees. Source: Mediobanca, BIS-BdI, and CNN Money. 
Table 7: Effects of general and specific announcements on banks' rates of return; fixed effects

\begin{tabular}{|c|c|c|c|c|c|c|c|c|}
\hline \multirow[b]{2}{*}{ COEFFICIENT } & \multicolumn{4}{|c|}{ All Announcements } & \multicolumn{4}{|c|}{ Announcements by type } \\
\hline & $\begin{array}{c}(1) \\
\text { All periods }\end{array}$ & $\begin{array}{c}\text { (2) } \\
\text { Subperiod } 1\end{array}$ & $\begin{array}{c}(3) \\
\text { Subperiod } 2\end{array}$ & $\begin{array}{c}(4) \\
\text { Subperiod } 3\end{array}$ & $\begin{array}{c}(5) \\
\text { All periods }\end{array}$ & $\begin{array}{c}\text { (6) } \\
\text { Subperiod } 1\end{array}$ & $\begin{array}{c}\text { (7) } \\
\text { Subperiod } 2\end{array}$ & $\begin{array}{c}(8) \\
\text { Subperiod } 3\end{array}$ \\
\hline$R_{m}$ & $1.405^{* * *}$ & $1.355^{* * *}$ & $1.331 * * *$ & $1.731 * * *$ & $1.405^{* * *}$ & $1.355^{* * *}$ & $1.332 * * *$ & $1.732 * * *$ \\
\hline SIZE & $0.00215^{* * *}$ & $0.00324 * * *$ & $0.0198 * * *$ & 0.00217 & $0.00211 * * *$ & $0.00324 * * *$ & $0.0198 * * *$ & 0.00251 \\
\hline$G$ & $0.00666^{* * *}$ & -0.00183 & $0.00465^{* * *}$ & $0.00290 *$ & & & & \\
\hline$G_{A P}$ & & & & & $0.00345^{* *}$ & 0 & $0.00455^{* *}$ & -0.0128 \\
\hline$G_{C I}$ & & & & & $0.00481 * * *$ & -0.00183 & 0.00216 & $0.00429 * *$ \\
\hline$G_{D G}$ & & & & & $0.00614 * * *$ & 0 & 0.00443 & -0.00916 \\
\hline$S$ & $-0.0119 * * *$ & $0.0179 *$ & $-0.0136 * * *$ & 0.00355 & & & & \\
\hline$S_{A P}$ & & & & & -0.0109 & 0 & -0.0243 & 0.00607 \\
\hline$S_{C I}$ & & & & & $-0.0137 * * *$ & 0 & $-0.0156^{* * *}$ & 0.00308 \\
\hline$S_{D G}$ & & & & & -0.00103 & $0.0179 *$ & 0.00637 & 0 \\
\hline Constant & $-0.0202 * * *$ & $-0.0315 * * *$ & $-0.180 * * *$ & -0.0187 & $-0.0198 * * *$ & $-0.0315 * * *$ & $-0.180 * * *$ & -0.0217 \\
\hline Observations & 61,467 & 34,354 & 14,697 & 12,416 & 61,467 & 34,354 & 14,697 & 12,416 \\
\hline Number of bank & 120 & 120 & 120 & 120 & 120 & 120 & 120 & 120 \\
\hline Adjusted $\mathrm{R}^{2}$ & 0.392 & 0.428 & 0.320 & 0.328 & 0.392 & 0.428 & 0.321 & 0.328 \\
\hline F-Test & $\begin{array}{c}9,984 \\
(0.000)\end{array}$ & $\begin{array}{c}6,814 \\
(0.000)\end{array}$ & $\begin{array}{c}2,544 \\
(0.000)\end{array}$ & $\begin{array}{c}1,547 \\
(0.000)\end{array}$ & $\begin{array}{c}4,993 \\
(0.000)\end{array}$ & $\begin{array}{c}6,814 \\
(0.000)\end{array}$ & $\begin{array}{c}1,273 \\
(0.000)\end{array}$ & $\begin{array}{c}885.3 \\
(0.000)\end{array}$ \\
\hline Hausman Test & $\begin{array}{c}36.00 \\
(0.000)\end{array}$ & $\begin{array}{c}23.61 \\
(0.000)\end{array}$ & $\begin{array}{c}208.8 \\
(0.000)\end{array}$ & $\begin{array}{c}47.71 \\
(0.000)\end{array}$ & $\begin{array}{c}36.81 \\
(0.000)\end{array}$ & $\begin{array}{c}23.61 \\
(0.000)\end{array}$ & $\begin{array}{c}284.6 \\
(0.000)\end{array}$ & $\begin{array}{c}-99.81^{(a)} \\
(1.000)\end{array}$ \\
\hline WALD $G S_{x}=0$ & $\begin{array}{c}52.06 \\
(0.000)\end{array}$ & $\begin{array}{c}1.618 \\
(0.198)\end{array}$ & $\begin{array}{c}12.72 \\
(0.000)\end{array}$ & $\begin{array}{c}1.562 \\
(0.210)\end{array}$ & $\begin{array}{c}18.20 \\
(0.000)\end{array}$ & $\begin{array}{c}1.618 \\
(0.198)\end{array}$ & $\begin{array}{c}5.560 \\
(0.000)\end{array}$ & $\begin{array}{c}1.907 \\
(0.0896)\end{array}$ \\
\hline F-Test $G_{A P}=G_{C I}$ & & & & & $\begin{array}{c}0.512 \\
(0.474)\end{array}$ & - & $\begin{array}{c}0.457 \\
(0.499)\end{array}$ & $\begin{array}{c}2.719 \\
(0.0991)\end{array}$ \\
\hline F-Test $G_{A P}=G_{D G}$ & & & & & $\begin{array}{c}1.677 \\
(0.195)\end{array}$ & - & $\begin{array}{c}0.00150 \\
(0.969)\end{array}$ & $\begin{array}{l}0.0927 \\
(0.761)\end{array}$ \\
\hline F-Test $G_{C I}=G_{D G}$ & & & & & $\begin{array}{c}0.382 \\
(0.537)\end{array}$ & - & $\begin{array}{c}0.301 \\
(0.583)\end{array}$ & $\begin{array}{c}4.237 \\
(0.0395)\end{array}$ \\
\hline F-Test $G_{A P}=G_{C I}$ & & & & & $\begin{array}{l}0.0959 \\
(0.757)\end{array}$ & - & $\begin{array}{c}0.222 \\
(0.638)\end{array}$ & $\begin{array}{l}0.0329 \\
(0.856)\end{array}$ \\
\hline F-Test $G_{A P}=G_{D G}$ & & & & & $\begin{array}{c}0.856 \\
(0.355)\end{array}$ & - & $\begin{array}{c}2.134 \\
(0.144)\end{array}$ & $\begin{array}{c}0.172 \\
(0.678)\end{array}$ \\
\hline F-Test $G_{C I}=G_{D G}$ & & & & & $\begin{array}{c}3.584 \\
(0.0583)\end{array}$ & - & $\begin{array}{c}3.747 \\
(0.0529)\end{array}$ & $\begin{array}{c}0.163 \\
(0.687)\end{array}$ \\
\hline $\mathrm{CAR}=G^{* 7}$ & $4.66 \%$ & - & $3.26 \%$ & $2.03 \%$ & & & & \\
\hline $\mathrm{CAR}=G_{A P} * 7$ & & & & & $2.42 \%$ & - & $3.19 \%$ & - \\
\hline $\mathrm{CAR}=G_{C I} * 7$ & & & & & $3.37 \%$ & - & - & $3.00 \%$ \\
\hline $\mathrm{CAR}=G_{D G} * 7$ & & & & & $4.30 \%$ & - & - & - \\
\hline $\mathrm{CAR}=S * 5$ & $-5.95 \%$ & $8.95 \%$ & $-6.80 \%$ & - & & & & \\
\hline $\mathrm{CAR}=S_{A P} * 5$ & & & & & - & - & - & - \\
\hline $\mathrm{CAR}=S_{C I} * 5$ & & & & & $-6.85 \%$ & - & $-7.80 \%$ & - \\
\hline $\mathrm{CAR}=S_{D G} * 5$ & & & & & - & $8.95 \%$ & - & - \\
\hline
\end{tabular}

NOTES: All estimations with fixed effects. See text for sub-period. $R_{m}=$ rate of market return; SIZE $=\ln ($ Market Capitalization in million USD); $G=$ general announcement; $S=$ specific announcement; $A P=$ Asset Guarantees and Purchase; $C I=$ Capital Injection; $D G=$ Debt Guarantees; Hausman Test vs. random effect model; $G S_{x}=$ all general and specific announcements; CAR $=$ Cumulative Abnormal Return. (a) fails to meet asymptotic assumption.

$* * * \mathrm{p}<0.01, * * \mathrm{p}<0.05, * \mathrm{p}<0.1$. P-values of tests in parentheses. 
Table 8: Effects of cross-area general announcements on banks' rates of return; fixed effects.

\begin{tabular}{|c|c|c|c|c|c|}
\hline \multirow{4}{*}{ COEFFICIENT } & \multicolumn{3}{|l|}{ EUROPE } & \multirow[t]{2}{*}{ PACIFIC } & \multirow[t]{2}{*}{ USA } \\
\hline & & GBP & EUR & & \\
\hline & (1) & (2) & (3) & (4) & (5) \\
\hline & Sub-period 2 & Sub-period 2 & Sub-period 2 & Sub-period 2 & Sub-period 2 \\
\hline$R_{m}$ & $1.183 * * *$ & $1.425 * * *$ & $1.138 * * *$ & $1.043 * * *$ & $1.608^{* * *}$ \\
\hline SIZE & $0.0155^{* * *}$ & $0.0261 * * *$ & $0.0125 * * *$ & $0.0168 * * *$ & $0.0223 * * *$ \\
\hline$G$ & $-0.00547 * *$ & $-0.0302 * *$ & $0.00449 *$ & $0.00428 * *$ & $0.0150 * * *$ \\
\hline$S$ & $-0.0120^{* *}$ & -0.0188 & -0.00522 & 0 & $-0.0162 * * *$ \\
\hline$X G_{U S A}$ & $0.00407^{*}$ & -0.00825 & 0.00339 & -0.00198 & 0 \\
\hline$X G_{\text {PACIFIC }}$ & $-0.00369 *$ & 0.00297 & $-0.00496^{* *}$ & $0.00703 * * *$ & -0.00311 \\
\hline$X G_{E U R O P E}$ & $-0.00439 * * *$ & -0.00551 & $-0.00369 * *$ & 0.00111 & $-0.00479 * *$ \\
\hline Constant & $-0.136 * * *$ & $-0.234 * * *$ & $-0.111 * * *$ & $-0.163 * * *$ & $-0.198 * * *$ \\
\hline Observations & 6002 & 718 & 4177 & 3160 & 5535 \\
\hline Number of bank & 49 & 6 & 34 & 26 & 45 \\
\hline Adjusted $\mathrm{R}^{2}$ & 0.260 & 0.0787 & 0.355 & 0.477 & 0.387 \\
\hline F-Test & 410.0 & 20.97 & 396.1 & 931.9 & 774.2 \\
\hline & $(0.000)$ & $(0.000)$ & $(0.000)$ & $(0.000)$ & $(0.000)$ \\
\hline Hausman Test & 59.57 & 6.944 & 47.32 & 36.55 & 85.17 \\
\hline & $(0.000)$ & $(0.435)$ & $(0.000)$ & $(0.000)$ & $(0.000)$ \\
\hline WALD $X G_{X}=0$ & 2.667 & 0.351 & 2.813 & 5.676 & 3.068 \\
\hline & $(0.0460)$ & $(0.788)$ & $(0.0378)$ & $(0.000700)$ & $(0.0466)$ \\
\hline $\mathrm{CAR}=G^{*} 7$ & $-3.83 \%$ & $-21.14 \%$ & $3.14 \%$ & $3.00 \%$ & $10.50 \%$ \\
\hline $\mathrm{CAR}=S * 5$ & $-6.00 \%$ & - & - & - & $-8.10 \%$ \\
\hline $\mathrm{CAR}=X G_{U S A} * 7$ & $2.85 \%$ & - & - & - & \\
\hline $\mathrm{CAR}=X G_{\text {PACIFIC }} * 7$ & $-2.58 \%$ & - & $-3.47 \%$ & $4.92 \%$ & - \\
\hline $\mathrm{CAR}=X G_{E U R O P E} * 7$ & $-3.07 \%$ & - & $-2.58 \%$ & - & $-3.35 \%$ \\
\hline
\end{tabular}

NOTES: All estimations with fixed effects. Sub-period 2 is from 15 September 2008 to 6 March 2009. $R_{m}=$ rate of market return; $S I Z E=\ln ($ Market Capitalization in million USD); $G=$ general announcement; $S=$ specific announcement; $X G_{A R E A}=$ across AREA general announcement; $A P=$ Asset Guarantees and Purchase; $C I=$ Capital Injection; $D G=$ Debt Guarantees; Hausman Test vs random effect model; $X G_{X}=$ all across-areas general announcements; CAR $=$ Cumulative Abnormal Return. ${ }^{* * *} \mathrm{p}<0.01, * * \mathrm{p}<0.05,{ }^{*} \mathrm{p}<0.1$. P-values of tests in parentheses. 
Table 9: Effects of cross-bank specific announcements on banks' rates of return; OLS

\begin{tabular}{|c|c|c|c|c|c|c|c|}
\hline COEFFICIENT & $\begin{array}{c}\text { BANK OF } \\
\text { AMERICA } \\
(1) \\
\text { Sub-period } 2\end{array}$ & $\begin{array}{l}\text { CITIGROUP } \\
\text { (2) } \\
\text { Sub-period } 2 \\
\end{array}$ & $\begin{array}{c}\text { JPMORGAN } \\
\text { (3) } \\
\text { Sub-period } 2 \\
\end{array}$ & $\begin{array}{c}\text { WELLS } \\
\text { FARGO } \\
(4) \\
\text { Sub-period } 2 \\
\end{array}$ & $\begin{array}{c}\text { GOLDMAN } \\
\text { SACHS } \\
(5) \\
\text { Sub-period } 2 \\
\end{array}$ & $\begin{array}{c}\text { AMERICAN } \\
\text { EXPRESS } \\
(6) \\
\text { Sub-period } 2 \\
\end{array}$ & $\begin{array}{c}\text { MORGAN } \\
\text { STANLEY } \\
\text { (7) } \\
\text { Sub-period } 2 \\
\end{array}$ \\
\hline$R_{m}$ & $2.269 * * *$ & $2.235 * * *$ & $1.760 * * *$ & $1.846^{* * *}$ & $1.499 * * *$ & $1.664 * * *$ & $2.570 * * *$ \\
\hline SIZE & 0.00483 & 0.00986 & 0.0157 & 0.0176 & 0.00719 & 0.00824 & -0.00340 \\
\hline$G$ & 0.0153 & 0.00266 & 0.00490 & 0.00187 & 0.00679 & -0.00103 & 0.0141 \\
\hline$S$ & $-0.0601 * *$ & -0.0133 & -0.0156 & $0.0537 * *$ & $-0.0500 *$ & 0.00734 & -0.0288 \\
\hline$X S_{B A N K}$ OF AMERICA & & $-0.0719 * *$ & -0.00767 & -0.0272 & -0.0212 & -0.00496 & -0.0178 \\
\hline$X S_{\text {CITIGROUP }}$ & -0.0223 & & $-0.0259 *$ & -0.0254 & 0.0162 & -0.000504 & 0.00224 \\
\hline$X S_{J P M O R G A N}$ & -0.0333 & 0 & & -0.0246 & 0 & $-0.0526^{* *}$ & 0 \\
\hline$X S_{\text {WELLS FARGO }}$ & $0.0846^{* * *}$ & $0.0845 * *$ & 0.0237 & & 0.00375 & $0.0505 * * *$ & -0.00715 \\
\hline$X S_{G O L D M A N ~ S A C H S}$ & 0 & -0.0333 & 0 & 0 & & 0 & 0 \\
\hline$X S_{A M E R I C A N}$ EXPRESS & 0.0315 & 0.0546 & 0.00607 & 0.0213 & 0.0154 & & 0.0418 \\
\hline$X S_{M O R G A N ~ S T A N L E Y}$ & 0 & 0 & 0 & 0 & 0 & 0 & \\
\hline Constant & -0.0497 & -0.0981 & -0.179 & -0.196 & -0.0749 & -0.0824 & 0.0382 \\
\hline Observations & 227 & 227 & 227 & 227 & 227 & 227 & 227 \\
\hline $\mathrm{R}^{2}$ & 0.539 & 0.435 & 0.588 & 0.511 & 0.579 & 0.668 & 0.576 \\
\hline F-Test & $\begin{array}{c}31.84 \\
(0.000)\end{array}$ & $\begin{array}{c}20.96 \\
(0.000)\end{array}$ & $\begin{array}{c}38.81 \\
(0.000)\end{array}$ & $\begin{array}{c}28.45 \\
(0.000)\end{array}$ & $\begin{array}{c}37.46 \\
(0.000)\end{array}$ & $\begin{array}{c}54.91 \\
(0.000)\end{array}$ & $\begin{array}{c}37.00 \\
(0.000)\end{array}$ \\
\hline WALD $X-A N N_{B A N K S}=0$ & $\begin{array}{c}2.673 \\
(0.0330 \\
\end{array}$ & $\begin{array}{c}2.555 \\
(0.0398) \\
\end{array}$ & $\begin{array}{c}1.676 \\
(0.157) \\
\end{array}$ & $\begin{array}{c}2.689 \\
(0.0321) \\
\end{array}$ & $\begin{array}{c}0.763 \\
(0.550) \\
\end{array}$ & $\begin{array}{c}2.429 \\
(0.0487) \\
\end{array}$ & $\begin{array}{c}0.348 \\
(0.845) \\
\end{array}$ \\
\hline $\mathrm{CAR}=G^{* 7}$ & - & - & - & - & - & - & - \\
\hline $\mathrm{CAR}=S * 5$ & $-30.05 \%$ & - & - & $26.85 \%$ & $-25.00 \%$ & - & $-30.05 \%$ \\
\hline $\mathrm{CAR}=X S_{B A N K}$ OF AMERICA $* 5$ & & $-35.95 \%$ & - & - & - & - & - \\
\hline $\mathrm{CAR}=X S_{\text {CITIGROUP }} * 5$ & - & & $-12.95 \%$ & - & - & - & - \\
\hline $\mathrm{CAR}=X S_{J P M O R G A N} * 5$ & - & - & & - & - & $-26.30 \%$ & - \\
\hline $\mathrm{CAR}=X S_{\text {WELLS FARGO }} * 5$ & $42.30 \%$ & $42.25 \%$ & - & & - & $25.25 \%$ & $42.30 \%$ \\
\hline $\mathrm{CAR}=X S_{G O L D M A N S A C H S} * 5$ & - & - & - & - & & - & - \\
\hline $\mathrm{CAR}=X S_{\text {AMERICAN EXPRESS }} * 5$ & - & - & - & - & - & & - \\
\hline $\mathrm{CAR}=X S_{\text {MORGAN STANLEY }} * 5$ & - & - & - & - & - & - & \\
\hline
\end{tabular}

NOTES: All estimations are OLS. Sub-period 2 is from 15 September 2008 to 6 March 2009. $R_{m}=$ rate of market return; $S I Z E=\ln ($ Market Capitalization in million USD); $G=$ general announcement; $S=$ specific announcement; Hausman Test vs random effect model; $X S_{B A N K S}=$ across BANKS specific announcements; CAR $=$ Cumulative Abnormal Return. ${ }^{* * *} \mathrm{p}<0.01,{ }^{* *} \mathrm{p}<0.05,{ }^{*} \mathrm{p}<0.1$. P-values of tests in parentheses. 
Appendix: List of banks included in market capitalization

\begin{tabular}{|c|c|c|c|}
\hline Area & Country & Bank Nr. & Bank Name \\
\hline \multirow{14}{*}{ Europe } & AT & 2 & ERSTE GROUP BANK AG, RAIFFEISEN INTL BANK HOLDING \\
\hline & $\mathrm{BE}$ & 2 & DEXIA SA, KBC GROEP NV \\
\hline & $\mathrm{CH}$ & 1 & VALIANT HOLDING AG-REG \\
\hline & $\mathrm{DE}$ & 3 & COMMERZBANK AG, DEUTSCHE POSTBANK AG, HYPO REAL ESTATE HOLDING \\
\hline & DK & 3 & DANSKE BANK A/S, JYSKE BANK-REG, SYDBANK A/S \\
\hline & ES & 6 & $\begin{array}{l}\text { BANCO BILBAO VIZCAYA ARGENTA, BANCO DE VALENCIA SA, BANCO } \\
\text { POPULAR ESPANOL, BANCO SANTANDER SA, BANKINTER SA }\end{array}$ \\
\hline & FR & 4 & BNP PARIBAS, CREDIT AGRICOLE SA, NATIXIS, SOCIETE GENERALE \\
\hline & GR & 5 & $\begin{array}{l}\text { ALPHA BANK A.E., BANK OF GREECE, EFG EUROBANK ERGASIAS, NATIONAL } \\
\text { BANK OF GREECE, PIRAEUS BANK S.A. }\end{array}$ \\
\hline & IE & 1 & ALLIED IRISH BANKS PLC \\
\hline & IT & 8 & $\begin{array}{l}\text { BANCA CARIGE SPA, BANCA MONTE DEI PASCHI SIENA, BANCA POPOLARE DI } \\
\text { MILANO, BANCO POPOLARE SCARL, INTESA SANPAOLO, PICCOLO CREDITO } \\
\text { VALTELLINESE, UBI BANCA SCPA, UNICREDIT SPA }\end{array}$ \\
\hline & NO & 1 & DNB NOR ASA \\
\hline & PT & 3 & BANCO BPI SA, BANCO COMERCIAL PORTUGUES, BANCO ESPIRITO SANTO \\
\hline & SE & 4 & $\begin{array}{l}\text { NORDEA BANK AB, SKANDINAVISKA ENSKILDA, SVENSKA HANDELSBANKEN } \\
\text { SHS, SWEDBANK AB }\end{array}$ \\
\hline & UK & 6 & $\begin{array}{l}\text { BANK OF IRELAND, BARCLAYS PLC, HSBC HOLDINGS PLC, LLOYDS BANKING } \\
\text { GROUP PLC, ROYAL BANK OF SCOTLAND, STANDARD CHARTERED PLC }\end{array}$ \\
\hline \multirow{3}{*}{ Pacific } & AU & 6 & $\begin{array}{l}\text { AUST AND NZ BANKING GROUP, BANK OF QUEENSLAND LTD, BENDIGO AND } \\
\text { ADELAIDE BANK, COMMONWEALTH BANK OF AUSTRALIA, NATIONAL } \\
\text { AUSTRALIA BANK LTD, WESTPAC BANKING CORP }\end{array}$ \\
\hline & HK & 8 & $\begin{array}{l}\text { BANK OF CHINA LTD, BANK OF COMMUNICATIONS CO, BANK OF EAST ASIA, } \\
\text { BOC HONG KONG HOLDINGS LTD, CHINA CONSTRUCTION BANK, HANG SENG } \\
\text { BANK LTD, HSBC HOLDINGS PLC, IND \& COMM BANK OF CHINA }\end{array}$ \\
\hline & JP & 12 & $\begin{array}{l}\text { BANK OF YOKOHAMA LTD, CHIBA BANK LTD, CHUO MITSUI TRUST HOLDINGS, } \\
\text { FUKUOKA FINANCIAL GROUP INC., MITSUBISHI UFJ FINANCIAL GROUP, } \\
\text { MIZUHO FINANCIAL GROUP INC, MIZUHO TRUST \& BANKING CO, RESONA } \\
\text { HOLDINGS INC, SHINSEI BANK LTD, SHIZUOKA BANK LTD, SUMITOMO MITSUI } \\
\text { FINANCIAL GROUP, SUMITOMO TRUST \& BANKING CO }\end{array}$ \\
\hline USA & US & 45 & $\begin{array}{l}\text { AMERICAN CAPITAL LTD, AMERICAN EXPRESS CO, AMERIPRISE FINANCIAL } \\
\text { INC, BANK OF AMERICA CORP, BANK OF NEW YORK MELLON CORP, BB\&T } \\
\text { CORP, CAPITAL ONE FINANCIAL CORP, CIT GROUP INC, CITIGROUP INC, CMA } \\
\text { GROUP INC, COMERICA INC, DISCOVERY FINANCIAL SERVICES, E*TRADE } \\
\text { FINANCIAL CORP, FEDERATED INVESTORS INC, FIFTH THIRD BANCORP, FIRST } \\
\text { HORIZON NATIONAL CORP, FRANKLIN RESOURCES INC, GOLDMAN SACHS } \\
\text { GROUP INC, HUDSON CITY BANCORP INC, HUNTINGTON BANCSHARES INC, } \\
\text { INTERCONTINENTALEXCHANGE INC, INVESCO LTD, JANUS CAPITAL GROUP } \\
\text { INC, JPMORGAN CHASE \& CO, KEYCORP, LEGG MASON INC, LEUCADIA } \\
\text { NATIONAL CORP, M \& T BANK CORP, MARSHALL \& ILSLEY CORP, MOODY'S } \\
\text { CORP, MORGAN STANLEY, NASDAQ OMX GROUP, NORTHERN TRUST COR, } \\
\text { NYSE EURONEXT, PEOPLE'S UNITED FINANCIAL, PNC FINANCIAL SERVICES } \\
\text { GROUP, REGIONS FINANCIAL CORP, SCHWAB (CHARLES) CORP, SLM CORP, } \\
\text { STATE STREET CORP, SUNTRUST BANKS INC, T ROWE PRICE GROUP INC, US } \\
\text { BANCORP, WELLS FARGO \& CO, ZIONS BANCORPORATION }\end{array}$ \\
\hline
\end{tabular}

NOTES: AT=Austria, $\mathrm{BE}=$ Belgium; $\mathrm{CH}=$ Switzerland; $\mathrm{DE}=$ Germany; $\mathrm{DK}=$ Denmark; $\mathrm{ES}=$ Spain; $\mathrm{FR}=$ France; $\mathrm{GR}=$ Greece; $\mathrm{IE}=$ Eire; IT=Italy; $\mathrm{NO}=$ Norway; $\mathrm{PT}=$ Portugal; $\mathrm{SE}=$ Sweden; UK=United Kingdom; AU=Australia; HK=Hong-Kong; $\mathrm{JP}=\mathrm{Japan}$; US=United States. Source: Bloomberg. 